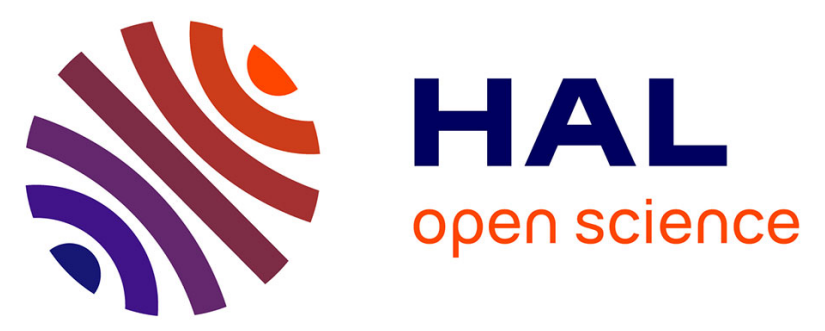

\title{
Middle to Late Miocene Age for the End of Amphibolite-Facies Mylonitization of the Alpine Schist, New Zealand: Implications for Onset of Transpression Across the Alpine Fault
}

Uwe Ring, Johannes Glodny, Samuel Angiboust, Tim Little, Karl A. Lang

\section{To cite this version:}

Uwe Ring, Johannes Glodny, Samuel Angiboust, Tim Little, Karl A. Lang. Middle to Late Miocene Age for the End of Amphibolite-Facies Mylonitization of the Alpine Schist, New Zealand: Implications for Onset of Transpression Across the Alpine Fault. Tectonics, 2019, 38, pp.4335-4359. 10.1029/2019TC005577 . insu-03586584

\section{HAL Id: insu-03586584 \\ https://hal-insu.archives-ouvertes.fr/insu-03586584}

Submitted on 24 Feb 2022

HAL is a multi-disciplinary open access archive for the deposit and dissemination of scientific research documents, whether they are published or not. The documents may come from teaching and research institutions in France or abroad, or from public or private research centers.
L'archive ouverte pluridisciplinaire HAL, est destinée au dépôt et à la diffusion de documents scientifiques de niveau recherche, publiés ou non, émanant des établissements d'enseignement et de recherche français ou étrangers, des laboratoires publics ou privés.

$$
\text { Copyright }
$$




\section{Tectonics}

\section{RESEARCH ARTICLE 10.1029/2019TC005577 \\ Key Points: \\ - We present the first quantitative data constraining the timing of Cenozoic Alpine Schistmylonitization and metamorphism \\ - We present evidence for middle Miocene crustal thickening in the Southern Alps of New Zealand \\ - The Alpine Schist has a distinct two-phase cooling history}

Supporting Information:

- Supporting Information S1

- Figure S1

- Table S1

- Table S2

- Table S3

- Table S4

- Table S5

Correspondence to:

U. Ring,

uwe.ring@geo.su.se

Citation:

Ring, U., Glodny, J., Angiboust, S., Little, T., \& Lang, K. A. (2019). Middle to late Miocene age for the end of amphibolite-facies mylonitization of the Alpine Schist, New Zealand: Implications for onset of transpression across the Alpine Fault. Tectonics, 38. 4335-4359. https://doi.org/10.1029/ 2019TC005577

Received 11 MAR 2019

Accepted 6 OCT 2019

Accepted article online 6 NOV 2019

Published online 18 DEC 2019 (c)2019. American Geophysical Union. All Rights Reserved.

\section{Middle to Late Miocene Age for the End of Amphibolite- Facies Mylonitization of the Alpine Schist, New Zealand: Implications for Onset of Transpression Across the Alpine Fault}

\author{
Uwe Ring $^{1}$ (D) Johannes Glodny ${ }^{2}$ (D), Samuel Angiboust ${ }^{2,3}$, Tim Little ${ }^{4}$, and Karl A. Lang ${ }^{5}$ \\ ${ }^{1}$ Institutionen för geologiska vetenskaper, Stockholms universitet, Stockholm, Sweden, ${ }^{2}$ Deutsches \\ GeoForschungsZentrum GFZ, Potsdam, Germany, ${ }^{3}$ Université de Paris, Institut de Physique du Globe de Paris, CNRS, \\ Paris, France, ${ }^{4}$ School of Earth Sciences, Victoria University, Wellington, New Zealand, ${ }^{5}$ School of Earth and \\ Environmental Sciences, Queens College, New York, NY, USA
}

\section{Introduction}

The Southern Alps of New Zealand is an obliquely convergent (transpressional) orogen formed by continental collision between the Australian and Pacific plates (Cox \& Sutherland, 2007; Furlong \& Kamp, 2009; Norris et al., 1990; Norris \& Toy, 2014; Walcott, 1998). Plate convergence is accommodated by dip-slip motion on the Alpine Fault, which locally attains $\sim 12 \mathrm{~mm} / \mathrm{a}$ (Norris \& Cooper, 2001), and by antithetic, reverse-oblique slip on faults distributed eastward across the orogen (Cox \& Findlay, 1995; Cox et al., 2012; Little, 2004). Since its $\sim 25 \mathrm{Ma}$ inception as a strike-slip fault accommodating horizontal motion on the Pacific-Australia plate boundary, the Alpine Fault has accrued a total dextral displacement of at least 460 km (Kamp, 1986; Norris \& Cooper, 2001; Norris \& Toy, 2014). A phase of rapid rock uplift and exhumation of Southern Alps topography has been attributed to a late Neogene increase in the rate of convergent motion. While there is an abundance of low-temperature thermochronologic ages constraining the PlioPleistocene exhumation history, comparatively few quantitative data exist on the timing and conditions under which oblique convergence and crustal thickening developed in the Miocene.

This article places new constraints on the pressure-temperature (P-T) conditions and timing of mylonitization of the Alpine Schist exposed directly above the central Alpine Fault. The Alpine Schist has a prolonged tectonic history since the Mesozoic, and there are challenges in distinguishing pre-Cenozoic tectonometamorphic overprints from initiation of oblique plate convergence and the formation of a crustal root in the Neogene. To circumvent these problems, we selected four mylonitic Alpine Schist samples and one mylonitic metapegmatite from locations directly above the Alpine Fault in the central Southern Alps (Figure 1). Mylonite offers the best opportunity to unambiguously measure Cenozoic age and P-T information, as in 


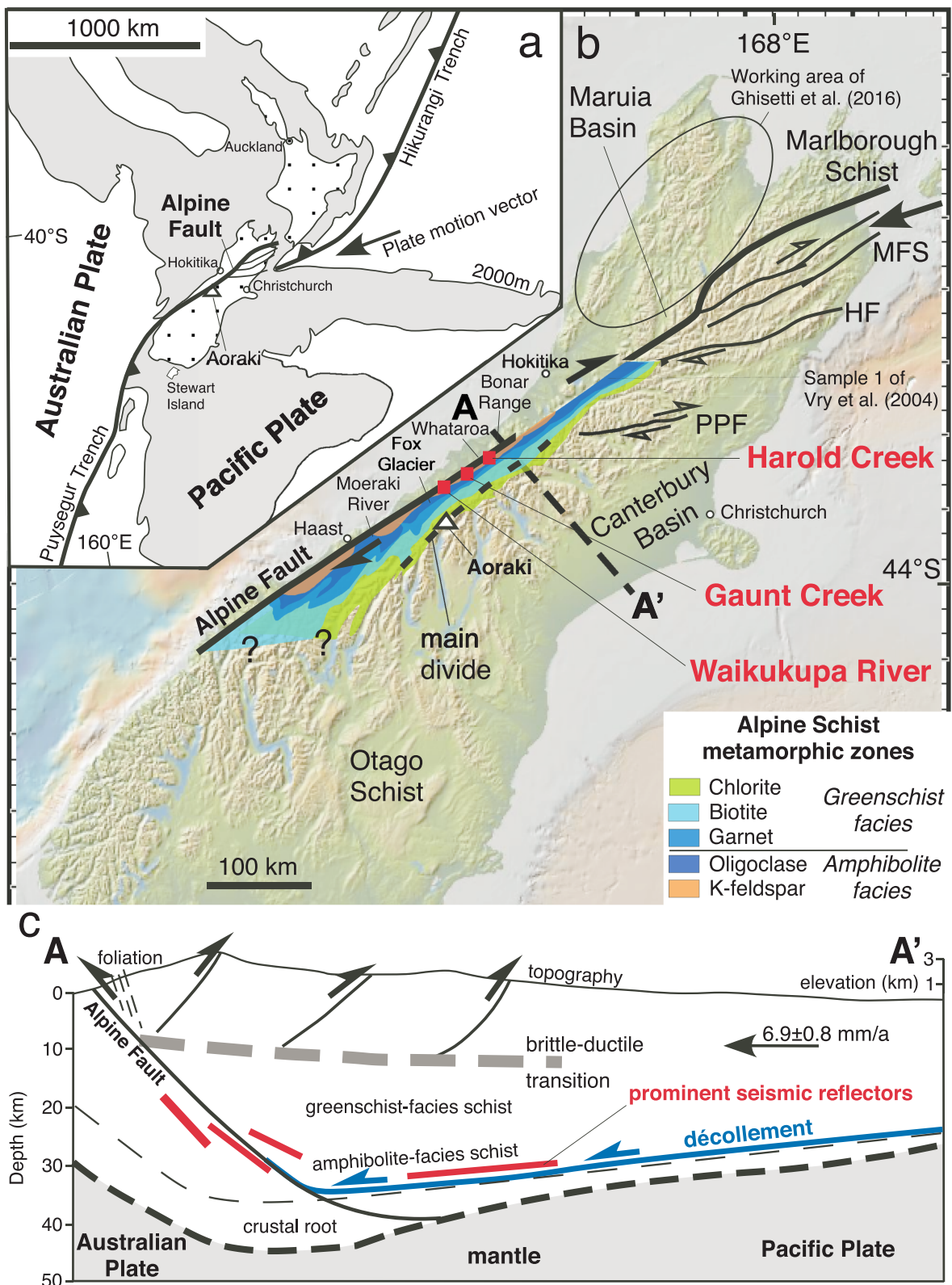

Figure 1. Tectonic context of Southern Alps. (a) Index map of Southern Alps and Alpine Fault of South Island, New Zealand, with Morvel plate motion vector (Pacific relative to Australian plate) (DeMets et al., 2010); gray area outlines Zealandia. (b) DEM of South Island showing Alpine Fault and metamorphic grade in Pacific-Plate rocks to east (note that only metamorphic zonation for central Southern Alps shown); also shown three sample localities of Alpine Schist mylonite (red squares); other localities mentioned in text and selected active faults; Figure 2 provides details of Harold and Gaunt Creek and Waikukupa River area. (c) Schematic cross-sectional cartoon A-A' showing selected tectonic features, prominent seismic reflectors (Stern et al., 2007), proposed midcrustal décollement inferred from seismic data, Alpine Schist metamorphism, and kinematic modeling (Little, 2004; Herman et al., 2007); dashed line marks base of quartzofeldspathic crust (Stern et al., 2007); crustal root beneath dashed line may be composed of Australian Plate rocks (Lamb et al., 2015). Note that Pacific Plate rocks move horizontally above décollement until they reach Alpine Fault ramp in west and motion becomes steep; in east, WSW moving material initially thickens across eastern "prowedge" (rainshadow region of slow erosion rate), then rocks ramp upward on Alpine Fault and removed efficiently by high erosion (zone of very high rainfall) at western "retrowedge" side of Southern Alps. HF = Hope fault; MFS = Marlborough fault system; PPF $=$ Porter's Pass fault. 
such rocks, older relics may have been strongly or even fully overprinted by pervasive deformation and associated fluid infiltration. The latter also enhances nucleation processes and the kinetics of mineral growth during mylonitization (Ague \& Carlson, 2013; Carlson, 2011; Skelton, 1997), potentially erasing earlier textural relics. In contrast, textural relics in coarse-grained metapegmatite have the potential to record premylonitization crystallization events (Glodny et al., 1998; Kumerics et al., 2005).

\section{Setting}

\subsection{Tectonic Setting}

Inception of a Pacific-Australian plate boundary dates back to $45 \mathrm{Ma}$ (Sutherland, 1995). Based on the age of dike swarms (Cooper et al., 1987), as well as patterns of changing sediment sources (King et al., 1999), the inception of the present-day Alpine Fault as a primarily strike-slip fault occurred at ca. $25 \mathrm{Ma}$ (Kamp, 1986). Seafloor spreading fabrics, reconstruction of the conjugate rifted margins south of New Zealand (Sutherland, 1995), and magnetic anomaly-based plate circuits of the Australian, Antarctica, and Pacific plates (Cande \& Stock, 2004; Walcott, 1998) argue for a gradational change of plate motion from initial strike-slip to dextral transpressive motion after ca. $25 \mathrm{Ma}$. The most recent estimate of Pacific Plate motion relative to the Australian Plate in the central South Island of New Zealand is $39.7 \pm 0.7 \mathrm{~mm} / \mathrm{a}$ on a bearing of $245 \pm 1^{\circ}$ (MORVEL model of DeMets et al., 2010). At Fox Glacier, the MORVEL plate motion has components of $39.1 \pm 0.7 \mathrm{~mm} /$ a parallel to the Alpine Fault and $6.9 \pm 0.8 \mathrm{~mm} /$ a perpendicular to the fault. There, the plate motion vector trends $18-20^{\circ}$ clockwise of the strike of the Alpine Fault, which takes up 55-80\% of the total margin-parallel component of Pacific-Australia plate motion (Norris \& Cooper, 2001).

One of the first-order expressions of Pacific-Australia plate convergence is the formation of a thick crustal root supporting Southern Alps topography. Quantitative data for the timing of initial crustal thickening and peak metamorphism are crucial for better understanding of mountain building along this plate boundary. Young $(\leq 6 \mathrm{Ma}){ }^{40} \mathrm{Ar} /{ }^{39} \mathrm{Ar}$ and $\mathrm{K}$-Ar hornblende, white mica, and biotite ages interpreted to date cooling resulting from rapid rock uplift and erosion along the Alpine Fault in the central Southern Alps suggest that crustal thickening must be at least this old (Adams, 1981; Batt et al., 2000; Little et al., 2005). However, Batt et al. (2004) reported regionally synchronous onset of rapid cooling at $~ 8$ Ma. Tippett and Kamp (1993) already proposed a start of rapid rock uplift near Haast at 8-7 Ma. Based on apatite fission track ages, Ring and Bernet (2010) called for a $>11$ Ma onset of crustal thickening and associated rock uplift in the Bonar Range directly below the Alpine Fault. Ghisetti et al. (2016) reported an even earlier onset of crustal shortening in the northwestern part of the Southern Alps, to the west of the Alpine Fault, in the early to middle Miocene. Findlay (1987), Holm et al. (1989), and Batt et al. (2000) speculated that the peak of metamorphism in the Alpine Schist could be at 20-15 Ma.

A common concept in models of Southern Alps mountain building is that the lithospheric mantle of the Pacific Plate delaminates and its lower crustal material is either added to the orogenic root or subducted with the Pacific lithospheric mantle (Figure 1c) (Kleffman et al., 1998; Okaya et al., 2007; Stern et al., 2007; Wellman, 1979). A subhorizontal midcrustal décollement is the key structure facilitating the westward movement (relative to the Australian Plate) of Pacific Plate rocks in a "conveyor belt" fashion (Koons, 1990) (Figure 1c). This “conveyor belt" concept is inherently asymmetric (Willett, 1999). It requires strongly focused slip on a single fault in the west, which currently is the Alpine Fault. Existence of the décollement is inferred from (1) seismic reflection and magnetotelluric data (Stern et al., 2007; Wannamaker et al., 2002). (2) The consistent maximum limit to exhumation depth ( 35-40 km, Grapes, 1995; Vry et al., 2004) as inferred from the metamorphic grade of Alpine Schist exposed along the Alpine Fault and the strongly asymmetric pattern of rapid exhumation across the present-day Southern Alps (Grapes, 1995; Little et al., 2005). No rocks of higher metamorphic grade than amphibolite facies are exposed anywhere along the fault despite the about $90 \mathrm{~km}$ of plate convergence across the Southern Alps. This evidence was used by Wellman (1979) to argue that the Alpine Fault merges downward into a subhorizontal décollement at midcrustal depths. (3) The GPS geodetic velocity pattern is also consistent with a present-day "conveyor belt" (Beavan et al., 2010, 2016). The depth of the midcrustal décollement is usually placed at $\sim 35 \mathrm{~km}$ at the base of the quartzofeldspathic crust (Stern et al., 2007). This estimate is based on the few available P-T estimates in exposed Alpine Schist (Grapes \& Watanabe, 1992, 1994; Grapes, 1995; Vry et al., 2004) and seismic data, both of which indicate that the hanging wall passes through depths of $35-40 \mathrm{~km}$. This depth lies above the seismically imaged, 
$\sim 45 \mathrm{~km}$ thick crustal root of the Southern Alps (Davey et al., 1998) (Figure 1c). Kinematic modeling of lowtemperature thermochronologic data predicts that a listric décollement might sole out at $\sim 35 \mathrm{~km}$ depth (Herman et al., 2007) (Figure 1c).

Rapid rock exhumation may explain the high geothermal gradient observed in the Southern Alps (Allis \& Shi, 1995; Kamp, 1997; Kamp et al., 1989; Koons, 1987; Toy et al., 2010). The geothermal gradient measured at $63 \pm 2{ }^{\circ} \mathrm{C} / \mathrm{km}$ at Gaunt Creek and $125 \pm 55^{\circ} \mathrm{C} / \mathrm{km}$ at Whataroa has been attributed to advection of heat in meteoric-derived fluids circulating between high ridges and deep Quaternary sediment-filled valleys oriented perpendicular to the fault (Sutherland et al., 2017). These very high gradients magnify an already elevated conductive geotherm and reflect transfer of heat from mountainous terrains into adjacent valleys (Stüwe \& Hintermüller, 2000). Therefore, the high gradients do not persist to great depths. Estimates of the geothermal gradient using geological criteria yield more conservative but still high depth-averaged values of about $40-50{ }^{\circ} \mathrm{C} / \mathrm{km}$, which primarily reflect crustal-scale conductive heat flow associated with advection of hot rocks from depth (Batt et al., 2000; Craw, 1997; Kidder et al., 2018; Ring et al., 2017; Toy et al., 2010). As a consequence of the high geothermal gradient, the modern brittle-ductile transition is $\leq 10 \mathrm{~km}$ deep (Leitner et al., 2001). The rapid exhumation and cooling rates are due to fast movement of rocks atop the Alpine Fault "conveyor belt," causing them to be rapidly eroded at the surface (Koons, 1990; Willett, 1999). The time of initiation of the "conveyor belt" is not known. High-grade schist detritus was found in sediments deposited at 4 Ma in the Waiho-1 drill hole (Sutherland, 1996), which implies rapid exhumation of the western Southern Alps began prior to this time. Extending this detrital record, fission track thermochronology of Waiho-1 sediments further suggests that exhumation of the western side of the orogen abruptly increased in the late Miocene at 8-7 Ma (Lang et al., 2018).

\subsection{Alpine Schist}

Erosion of the uplifted and tilted crustal section in the Pacific Plate has exhumed the Alpine Schist in a 10-20 km wide strip directly above the Alpine Fault (Figure 1b). The metamorphic grade increases westward from chlorite zone (greenschist facies) near the main (topographic) divide of the central Southern Alps, 12-15 km east of the Alpine Fault, to garnet-oligoclase and partly K-feldspar zone (amphibolite facies) adjacent to the Alpine Fault (Grapes, 1995; Scott et al., 2015) (Figure 1b). The intensity and degree of deformation also increases westward (Little et al., 2002; Norris \& Cooper, 2003) (Figure 2). The Alpine Schist consists of metamorphosed quartzofeldspathic greyschist; however, deeply exhumed pelitic, mafic, and quartzose rocks also occur closer to the Alpine Fault.

Deformation fabrics, metamorphic isograds, and published geochronology of the Alpine Schist illustrate that the Southern Alps orogen has a polymetamorphic and polydeformational history (Cooper, 1980; Grapes \& Watanabe, 1992, 1994; Grapes, 1995; Little et al., 2002; Mortimer, 2000; Mortimer \& Cooper, 2004; Scott et al., 2015; White, 1996; Yardley, 1982). A $~ 0.5-1.5 \mathrm{~km}$ thick mylonite zone occurs immediately east of the Alpine Fault (Little et al., 2005; Norris \& Cooper, 1995; Sibson et al., 1981) (Figure 2). Mylonitic fabrics in the Alpine Schist largely reflect amphibolite-facies deformation. The generally accepted interpretation is that the mylonitic fabrics are Pliocene and younger in age. However, back-calculation of the current exhumation rates in conjunction with P-T estimates suggests that the mylonitic fabrics may have formed before $6.4 \pm 2.4 \mathrm{Ma}$ (Vry et al., 2004) (see below for more details). Rocks adjacent to the Alpine Fault also record a transient phase of deep embrittlement and backshearing related to upward ramping of the Pacific Plate rocks onto the dipping plane of the Alpine Fault (Little et al., 2002; Little \& Holcombe, 2002; Little, 2004; Norris \& Cooper, 2007) (Figure 1c).

Outside the mylonite zone, the foliation in the Alpine Schist strikes NNE, approximately orthogonal to the direction of present-day maximum geodetic shortening, and $\sim 15^{\circ}$ anticlockwise to the strike of the more easterly striking Alpine Fault (Holm et al., 1989; Little et al., 2002, 2007) (Figure 2). Closer to the fault, a younger mylonitic foliation strikes subparallel to the Alpine Fault and dips $\sim 25-60^{\circ} \mathrm{SE}$, depending on local variability in the strike and kinematics of Alpine Fault segments (Norris \& Cooper, 1995). Pervasive greenschist-facies reworking and cataclasis affect rocks within $\sim 30-50 \mathrm{~m}$ of the Alpine Fault (Little et al., 2002; Sibson et al., 1981). The foliation generally steepens in its southeast dip with increasing distance eastward from the Alpine Fault, whereas the foliation dips gently to moderately within the mylonite zone (Figure 2). In the nonmylonitic Alpine Schist, an older foliation of pre-Neogene age dips steeply to the southeast or is subvertical (Little et al., 2002) (Figure 2). In rocks of the lowest metamorphic grade and at higher 


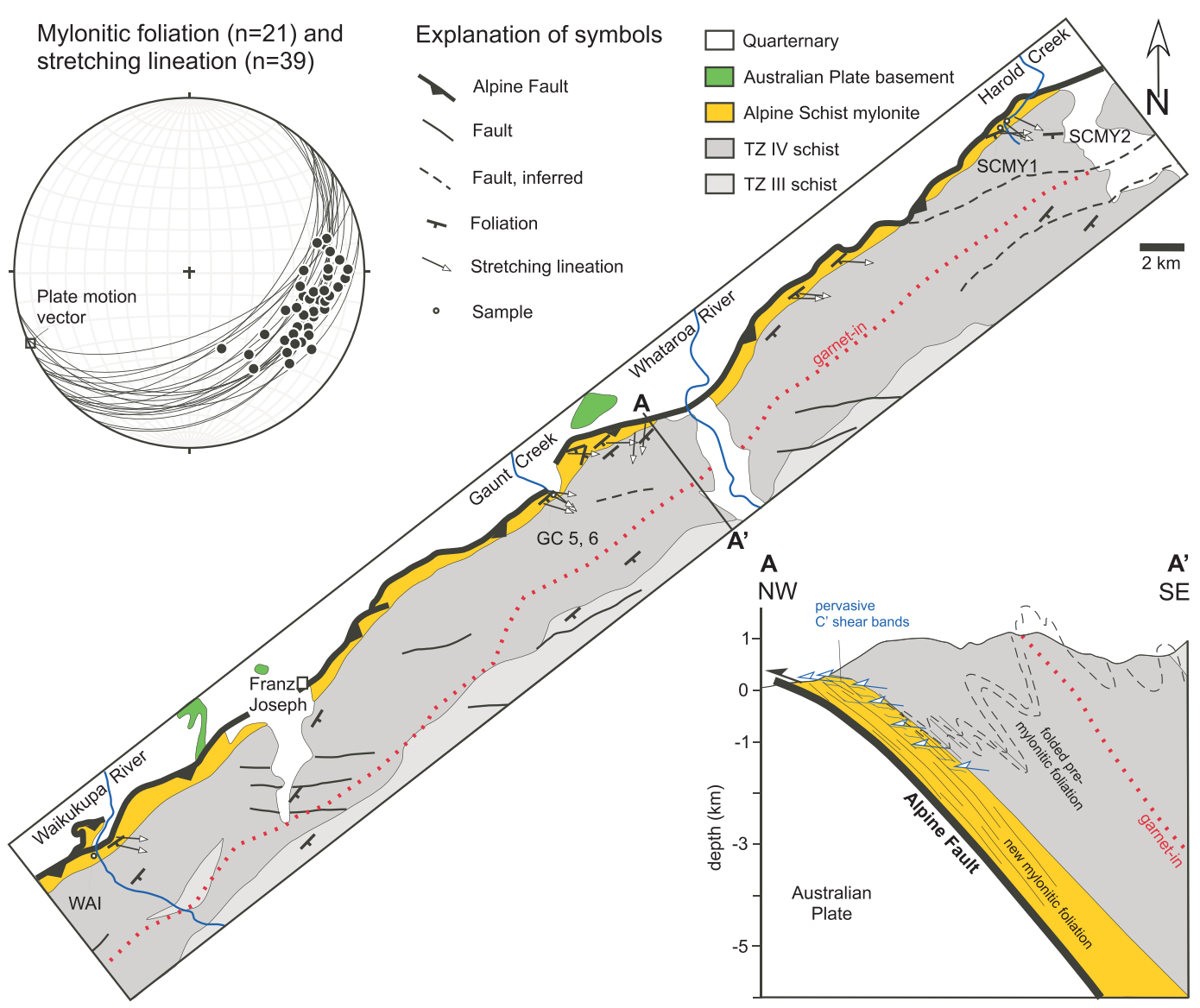

Figure 2. Tectonic map of Harold and Gaunt Creek and Waikukupa River area (see Figure 1 for location of creeks and rivers) showing structural data on map and in stereonet, garnet-in isograd, sample localities, and cross section A-A'; note that strike of faults compatible with Riedel shear orientations. Cross section schematically shows premylonitic foliation in SE and transposition of it toward Alpine Schist mylonite zone above Alpine Fault; amphibolite-facies mylonitic foliation overprinted by pervasive greenschist-facies $\mathrm{C}^{\prime}$ shear bands, both sets of structures record same kinematics. Modified from Cox and Barrell (2007) and Little et al. (2005).

structural levels far to the east of the Alpine Fault, still older fabrics in the nonmylonitic schist predate the main, steeply dipping, nonmylonitic Alpine foliation (Little et al., 2005).

The timing of amphibolite-facies metamorphism and mineral growth in the Alpine Schist is not well understood. The main metamorphic isograds strike subparallel to the Alpine Fault and are inferred to be parallel to or more steeply dipping than the fault (Cox \& Findlay, 1995; Findlay, 1987; Grapes \& Watanabe, 1992; Little et al., 2002). Despite this spatial correlation, the major metamorphic isograds and the dominant foliation are often correlated with a Mesozoic phase of metamorphism unrelated to formation of the present Southern Alps (Cooper, 1974; Craw et al., 1994; Findlay, 1987; Grapes, 1995; Grapes \& Watanabe, 1992, 1994; Holm et al., 1989). Recent age estimates for that metamorphism, and by inference for the timing of peak metamorphic conditions, range from 120-100 to 68 Ma (Briggs et al., 2018; Chamberlain et al., 1995; Grapes, 1995; Mortimer \& Cooper, 2004; Scott et al., 2015). Vry et al. (2004) obtained an imprecise Sm-Nd age of $12 \pm 37 \mathrm{Ma}$ from a Cenozoic garnet rim (Zone 4 garnet in their nomenclature), demonstrating a Cenozoic tectonometamorphic overprint of the Alpine Schist, which they quantified at $580-620^{\circ} \mathrm{C}$ and $1-$ $1.15 \mathrm{GPa}$ (equivalent to $37-45 \mathrm{~km}$ depth if an average mineral density of $2,700 \mathrm{~kg} / \mathrm{m}^{3}$ was assumed). Vry et al. (2004) identified an even younger phase of garnet growth (Zone 5 garnet) overgrowing an amphibolite-facies Alpine Schist mylonite fabric. By applying late Quaternary to Recent exhumation rates of 8-10 $\mathrm{km} / \mathrm{Myr}$ (Hovius et al., 1997; Simpson et al., 1994), they inferred an age of 6.4 \pm 2.4 Ma for this youngest garnet-growth phase. However, million year-scale exhumation rates based on low-T thermochronologic data are markedly smaller. Kamp et al. (1989) reported exhumation rates of $2.3-2.5 \mathrm{~km} / \mathrm{Myr}$ from $\sim 5.5$ to $1 \mathrm{Ma}$ 
and a higher rate of $6.2 \mathrm{~km} / \mathrm{Myr}$ from $\sim 1 \mathrm{Ma}$ to the present. Such smaller rates would make the inferred growth age for Zone 5 garnet of Vry et al. (2004) distinctly older (garnet growth at about $15 \mathrm{Ma}$ if $1.1 \mathrm{GPa}$ pressure, slip along a $45^{\circ}$-dipping Alpine Fault, and an exhumation rate of $2.5 \mathrm{~km} / \mathrm{Myr}$ was also used for the time before $\sim 5.5 \mathrm{Ma}$, i.e., from 15 to $1 \mathrm{Ma}$ ).

Ring et al. (2017) dated fault gouge from cataclasite/gouge layers interleaved within mylonitic Alpine Schist at Gaunt Creek and Harold Creek by the ${ }^{40} \mathrm{Ar} /{ }^{39} \mathrm{Ar}$ isochron method. The upper intercept age of the gouge isochron dates the original growth age of the metamorphic white mica. Fault gouge at Gaunt Creek yielded an upper intercept age of $2.04 \pm 0.3 \mathrm{Ma}$, whereas fault gouge at Harold Creek has an upper intercept at 11.46 $\pm 0.47 \mathrm{Ma}$.

$\mathrm{K}$-Ar and ${ }^{40} \mathrm{Ar} /{ }^{39} \mathrm{Ar}$ hornblende, white mica, and biotite ages from amphibolite-facies Alpine Schist in the central Southern Alps range between 6 and 1.5 Ma and are usually interpreted as cooling ages related to rapid exhumation associated with greenschist-facies and cataclastic thrusting along the Alpine Fault ramp (Adams, 1981; Batt et al., 2000; Little, 2004).

\section{Samples and Deformation}

We collected five samples of Alpine Schist mylonite for $\mathrm{Rb}-\mathrm{Sr}$ and ${ }^{40} \mathrm{Ar} /{ }^{39} \mathrm{Ar}$ age dating, as well as estimating P-T conditions. Mylonite samples SCMY1 and SCMY2 are from Harold Creek, samples GC5 and GC6 are from Gaunt Creek, and metapegmatite sample WAI is from Waikukupa River $\left(43.4437^{\circ} \mathrm{S}, 170.07011^{\circ} \mathrm{E}\right)$ (Figure 2). Outcrop descriptions and sample coordinates of the Harold and Gaunt Creek sample localities are published in Ring et al. (2017). Here we provide additional outcrop photos and document the relationship between garnet growth and mylonitization (Figures 3a-3d), which allows linking metamorphism as deduced from matrix minerals and garnet rims with the muscovite-based age data. $\mathrm{C}^{\prime}$ shear bands (Passchier \& Trouw, 2005) in Figures 3a-3c show a top-to-the-W shear sense affecting an older foliation that developed during garnet growth. The older foliation appears higher grade than the shear bands, the latter of which formed during greenschist-facies conditions. Garnet in the older foliation is often chloritized to varying degrees, indicating exhumation-related greenschist-facies overprinting (Figures 3a-3d). Because we are interested in constraining early crustal thickening in the Southern Alps, we focused on samples with minimal postmylonitic overprinting (Figures 3e-3h). Detailed descriptions of the five samples are provided in the supporting information.

Our samples from Harold and Gaunt Creek show a relationship between garnet growth and ductile mylonitic deformation. Mylonitization includes K-feldspar recrystallization, implying temperatures $\geq 500^{\circ}$ (Passchier \& Trouw, 2005). Grapes (1995) and Grapes and Vry (1999) showed that some garnet growth accompanied mylonitization. Vry et al. (2004, p.147) analyzed one sample (their sample 1) from $<100 \mathrm{~m}$ east of the Alpine Fault (Figure 1) in detail. They showed that Cenozoic garnet rims (zone 4 garnet) formed with the mylonitic foliation and both the garnet rims and the mylonitic foliation were overgrown by a postmylonitic garnet growth phase forming outermost rims (zone 5 garnet). The garnets usually have older, preNeogene garnet cores and have complicated textures (Vry et al., 2004).

Textural relations suggest that in our samples, the entire garnet grains formed during mylonitic shearing (Figures 3e-3g), although some garnet microstructures might be interpretable as being interkinematic (Figure 3g). The mylonitic foliation is continuous between garnet and the matrix and slightly bent internally (Figures 3e, 3f, and 3h) indicating that garnet grew on the developing foliation, that is, syntectonic with the mylonitic foliation. However, in Figure 3g, the garnet does not appear to be syntectonic with the last (mylonitic) deformation, which is probably associated with the upper greenschist-facies $C^{\prime}$ shear bands, because a sharp bend is present between the internal and external fabric at the garnet contact. Assuming that all garnets have grown in the same kinematic regime, we propose that garnet grew during a phase of deformation generating the main muscovite-biotite-ilmenite mylonitic foliation in the rock and created the syntectonic inclusion patterns. After this garnet growth event, mylonitic $\mathrm{C}^{\prime}$ shear bands developed, and the older foliation was reworked, probably in a strain field with similar orientation (possibly a change in the vorticity of flow). Garnet remained stable but did not continue to grow. The observation that there is no great angle between the internal and external fabrics may also be an indication for separate development of shear-band foliation overprint in a later stage of development. However, it is possible that all structures developed in a continuous tectonic event, where deformation conditions changed gradually. 

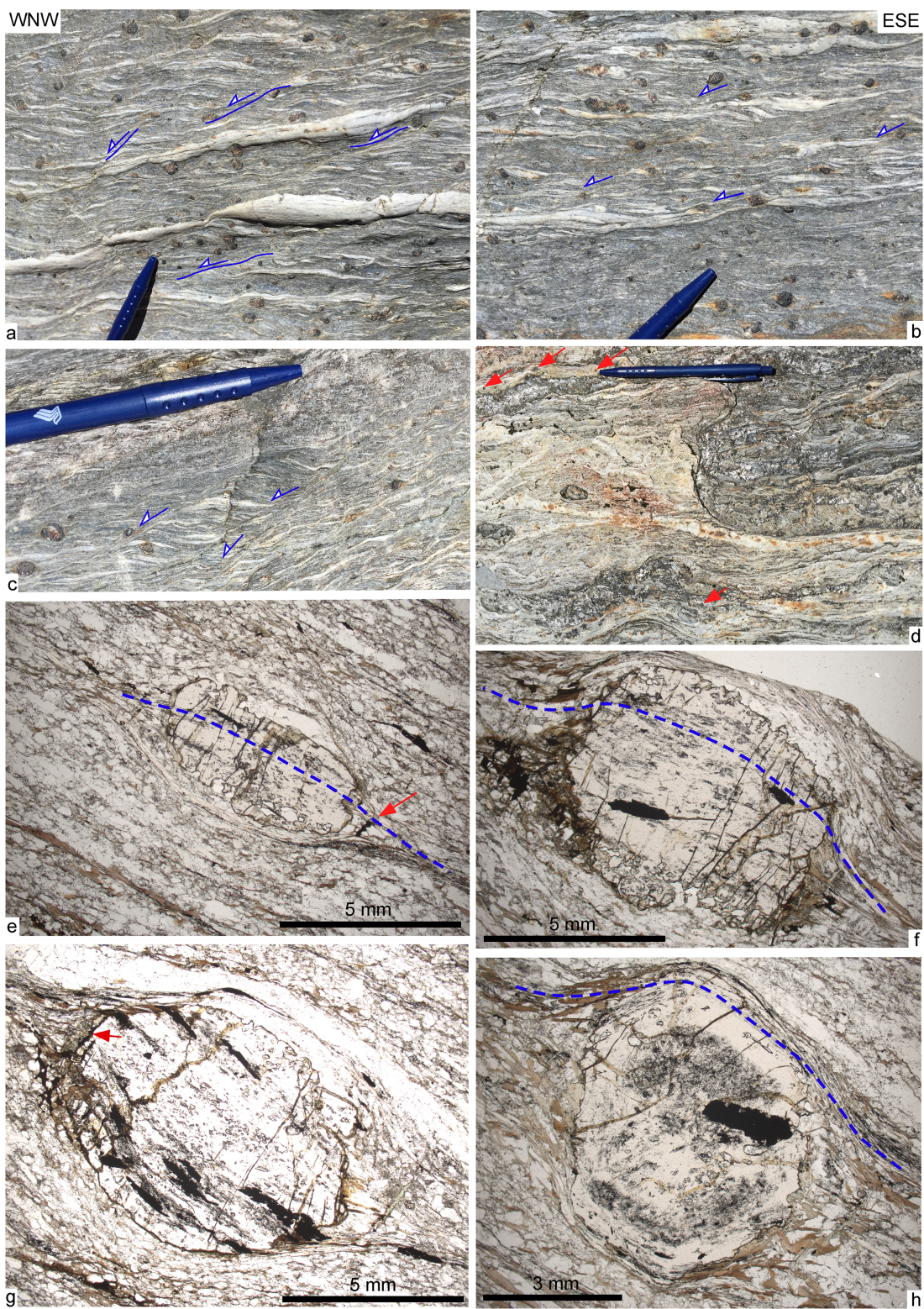

Figure 3. (a-c) Outcrop photographs from Harold Creek. Garnet in mylonitic metasediment commonly chloritized at rim; some garnet severely chloritized, while few show no chloritization. Most asymmetric strain shadows around garnet provide same top-W shear sense as $\mathrm{C}^{\prime}$ shear bands in matrix ( $\mathrm{C}^{\prime}$ shear bands highlighted by blue lines and arrows). $\mathrm{C}^{\prime}$ shear bands formed during greenschist-facies mylonitization and affect older foliation (including garnet) that appears higher grade than shear bands. Outcrops oriented approximately parallel to stretching lineation and perpendicular to mylonitic foliation. (d) Gaunt Creek locality where GC5 and GC6 were collected. Note that garnet grows in quartz-oligoclase segregations (red arrows). (e-h) Microphotographs showing relation between internal foliation in garnet $\left(\mathrm{S}_{\mathrm{i}}\right)$, strain shadows around garnet, and matrix foliation $\left(\mathrm{S}_{\mathrm{e}}\right)$ in sample GC6. Note missing chloritization of garnet and biotite. Blue dashed line indicates foliation. (e) Elongated garnet with $\mathrm{S}_{\mathrm{i}}$ subparallel $\mathrm{S}_{\mathrm{e}}, \mathrm{S}_{\mathrm{e}}$ wraps around garnet, at left end of garnet continuity between $S_{i}$ and $S_{e}$, at right end garnet resorbed and biotite grows in embayment. Garnet distinctly flattened perpendicular to foliation. Red arrow shows small vein filled with chlorite and opaques cutting across foliation. (f) Garnet with $S_{i}$ made up by fine graphite and elongated ilmenite, $S_{i}$ subparallel to $S_{e}$, small garnet rim shows hardly any $S_{i}$ at top end of garnet, bottom end resorbed, biotite growing in strain shadows. (g) Garnet with $\mathrm{S}_{\mathrm{i}}$ made up by fine graphite and elongated ilmenite, ilmenite continues from garnet into strain shadows, $\mathrm{S}_{\mathrm{e}}$ (subparallel to $\mathrm{S}_{\mathrm{i}}$ ) wraps around garnet, garnet does not appear syntectonic with last (mylonitic) deformation since sharp bend present between internal and external fabric at garnet contact. Red arrow shows chlorite and opaques growing at interface between garnet and its strain shadow overgrowing mylonitic foliation. (h) Cloudy graphite and ilmenite in garnet core hardly oriented, outermost rim has graphite inclusions forming $\mathrm{S}_{\mathrm{i}}$ that has continuity with $\mathrm{S}_{\mathrm{e}}$, bent strain caps of garnet overgrown indicating syntectonic garnet growth on developing foliation. 
Quartz in our mylonitic samples is typically $>100 \mu \mathrm{m}$, annealed, and depicts straight grain boundaries. Mancktelow and Pennacchioni (2004) showed that such microstructures are typical for fluid-saturated mylonitization. Skelton (1997) argued that in zones of pervasive fluid flow nucleation and thermally accelerated diffusion-controlled growth of garnet is strongly enhanced. Garnet with bell-shaped MnO growth profiles was interpreted to have grown as a result of pervasive fluid flow along interconnected grain boundaries (Skelton, 1997), which is typical for mylonitic deformation.

There is evidence for minor chloritization of garnet and biotite in our samples (Figures $3 \mathrm{e}$ and $3 \mathrm{~g}$ ). In other mylonitic rocks, chloritization of garnet is more severe (Figures 3a-3d). The degree of chloritization is increasing toward the Alpine Fault and related to the young $(<2 \mathrm{Ma})$ phase of rapid exhumation recorded in the currently exposed Alpine Schist (Little et al., 2002). The structures in amphibolite-facies mylonite and in the zones of later pervasive $\mathrm{C}^{\prime}$ shear bands and cataclasis are concordant and record the same kinematics (top-to-the-W transpressional shearing).

\section{Data}

The methods used for geothermobarometry and geochronology are detailed in the supporting information.

\subsection{Microstructures and Mineral Chemistry}

We studied two representative samples of garnet-bearing mylonitic schist (GC6 and SCMY2) in detail for deriving P-T conditions of mylonitization. The samples exhibit aligned muscovite and biotite flakes parallel to the main foliation. Dark, micrometer-scale oxide fringes under the optical microscope suggest some activity of pressure-solution creep together with crystal-plastic deformation during mylonitization. Millimeter-sized garnet porphyroblasts are either wrapped by the mylonitic foliation, or the mylonitic foliation in the matrix continues into the garnet (Figures $3 \mathrm{e}$ and $3 \mathrm{f}$ ). The mylonitic foliation is mainly composed of quartz-plagioclase-rich bands separated by mica-rich domains. Garnet contains inclusions of zoisite, quartz, rutile, and ilmenite. Garnet is enriched in $\mathrm{Mn}$ and $\mathrm{Ca}$ in the cores, with $\mathrm{Fe}$ and $\mathrm{Mg}$ increasing towards the rims (Figures $4 \mathrm{a}, 4 \mathrm{~b}$, and $5 \mathrm{a}$ ). Zoisite only occurs as inclusions in garnet and has a composition between $\mathrm{X}_{\mathrm{Ps}} 0.14$ and $0.21\left(\mathrm{X}_{\mathrm{Ps}}=\mathrm{Fe}^{3+} / \mathrm{Fe}^{3+}+\mathrm{Al}\right)$. Biotite is found in several microstructural settings: (i) in garnet strain shadows (Figure 4b), (ii) rimming muscovite in the matrix (Figure 4c), (iii) as mica fish in the foliation (Figure 4d), (iv) interleaved with muscovite and ilmenite in the foliation (Figure 4e), and (v) filling garnet fractures along with muscovite (Figure 4f). Biotite composition is influenced by its setting (Figure $5 \mathrm{~b}$ ). Biotite near garnet is richer in $\mathrm{Fe}\left(\mathrm{X}_{\mathrm{Mg}}=0.3\right)$ than biotite flakes in the matrix $\left(\mathrm{X}_{\mathrm{Mg}}=0.45\right)$. Biotite is often closely associated with ilmenite in the main foliation (Figure 4d). Muscovite crystals are found in the same microstructural sites as biotite, which suggests the two minerals were in equilibrium during most of the mylonitic deformation recorded in these samples. Muscovite composition is homogeneous in both samples, ranging between $\mathrm{Si}=3.14$ and 3.2 atoms per formula unit (Figure 5c). Five micrometer thick bright rims are sometimes visible around muscovite flakes in back-scattered-electron mode: These are characterized by slightly higher celadonite content. Plagioclase composition ranges from $\mathrm{Ab}_{84} \mathrm{An}_{15} \mathrm{Or}_{1}$ (cores) to $\mathrm{Ab}_{77} \mathrm{An}_{22} \mathrm{Or}_{1}$ (rims; Figure 5d). Apatite is common as $100 \mu \mathrm{m}$ large elongated grains in the main foliation.

Garnet growth zoning indicates that the crystals are mono-metamorphic and therefore different from the complexly zoned garnet crystals reported by Vry et al. (2004). The enrichment of Mn and Ca in the cores of our garnets is similar to the enrichment $\mathrm{Mn}$ and $\mathrm{Ca}$ in clear, euhedral rims that overgrow preexisting strain shadows or include segments of the mylonitic foliation as reported in Little et al. (2002) from complexly zoned garnets. Little et al. (2002) concluded that those garnet rims grow synkinematic to late kinematic with respect to the mylonitic foliation. In line with most workers, we envisage that the thermal peak of metamorphism predates the post-Pliocene phase of oblique transpression (see summary in Little et al., 2002).

A retrograde, lower greenschist-facies overprint is expressed in the samples as (i) chlorite rims around biotite and to a lesser extent, garnet and (ii) the pseudomorphic replacement of plagioclase by aggregates of muscovite, albite, and orthoclase. Amphibole is not present in either of the samples. 

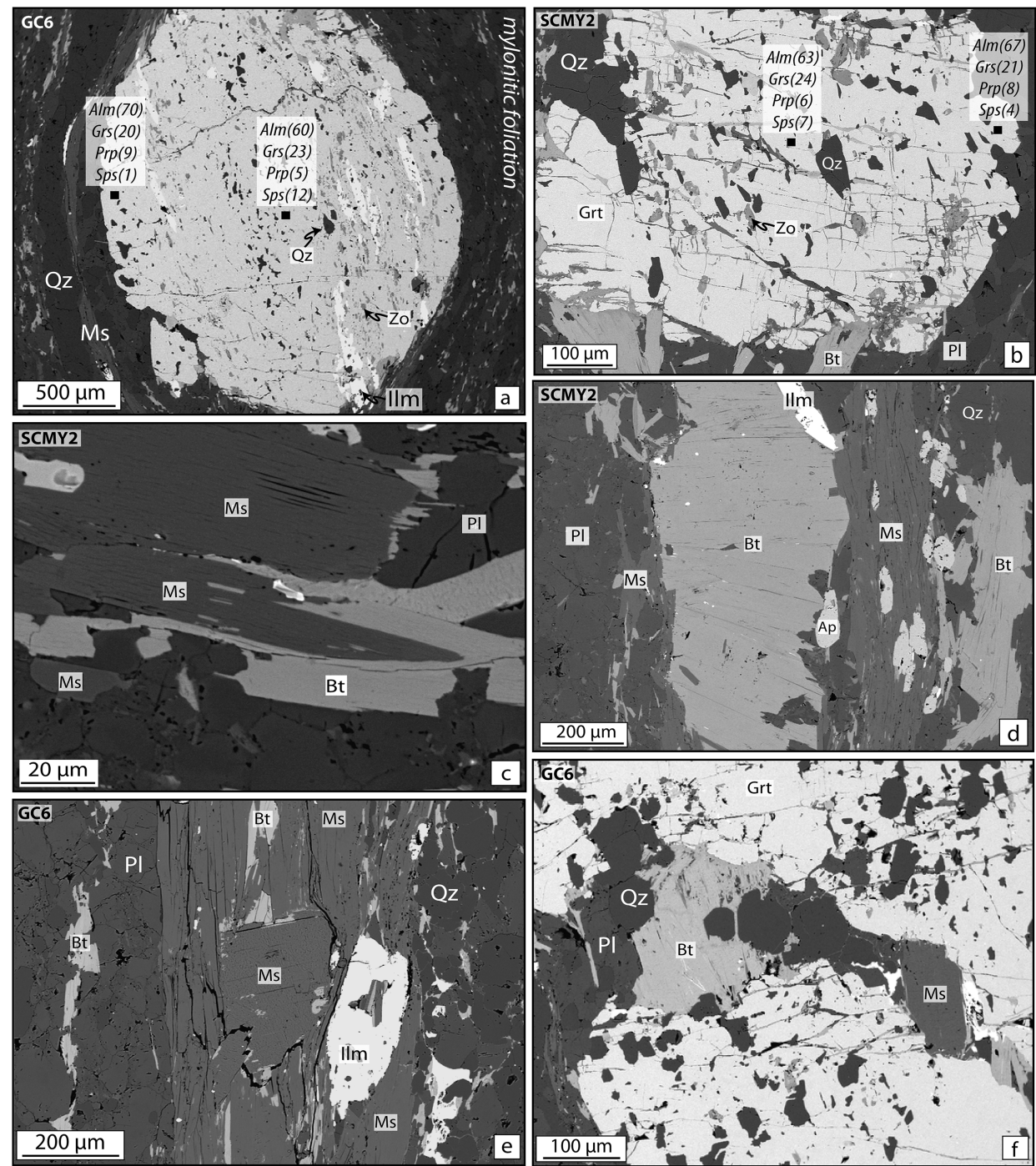

Figure 4. Back-scattered-electron images showing textural relationships in samples GC6 and SCMY2. (a) Large, rounded garnet porphyroblast showing oriented trail of inclusions, wrapped by mylonitic foliation. (b) Garnet containing ilmenite, zoisite, quartz, and rutile inclusions; biotite crystallized in strain shadow. (c) Close up of muscovitic white mica showing thin overgrowth of biotite. (d) Biotite with cracks perpendicular to mylonitic foliation made up of muscovite, biotite, plagioclase, ilmenite, quartz, and apatite. (e) Muscovite fish in muscovite + biotite + ilmenite foliation. (f) Close up of garnet fracture in which biotite, quartz, plagioclase, and muscovite grew.

\subsection{Pseudosection Modeling}

The P-T grid for mylonite sample SCMY2 has been calculated between 510 and $640{ }^{\circ} \mathrm{C}$ and 0.6 and $1.4 \mathrm{GPa}$ (Figure 6). The pseudosection also contains isopleths of the silica content (in atoms per formula unit) of white mica, the anorthite content of plagioclase (mol.\%), and $\mathrm{X}_{\mathrm{Mg}}$ and $\mathrm{X}_{\mathrm{Ca}}$ isopleths (mol.\%) of garnet. Our results show that the best fit region for the peak mylonitic assemblage is at $560-570{ }^{\circ} \mathrm{C}$ and $0.9-1.1$ $\mathrm{GPa}$ (equivalent to $33-41 \mathrm{~km}$ depth) in the plagioclase-white mica-biotite-garnet-chlorite-rutile field. This best fit region is based on the observed peak paragenesis and the crossing of mineral isopleths. Our P-T estimates are, within errors $\left( \pm 30^{\circ} \mathrm{C}\right.$; Palin et al., 2016), in agreement with those from Vry et al. (2004). Garnet rims, in textural equilibrium with the matrix, are considered to reflect peak metamorphic conditions. We use the grossular and pyrope content of garnet to constrain temperatures in the model. The pressure is quantified by combining the anorthitic component of plagioclase with the silica content of white mica, which lies in the mylonitic foliation and is in textural equilibrium with biotite. Importantly, modeled peak mineral proportions as well as mineral compositions are in good agreement with the mineral data (see comparison in 

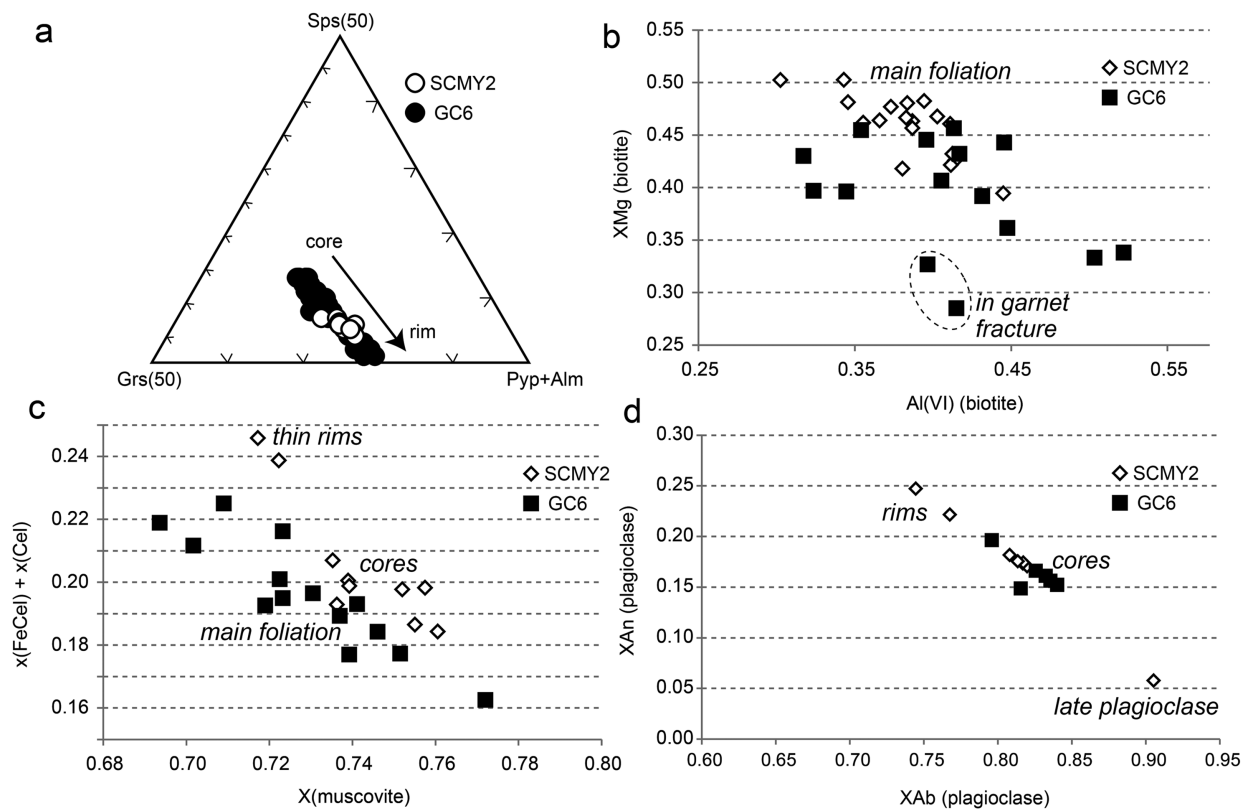

Figure 5. (a) Garnet composition of GC6 and SCMY2. (b) $\mathrm{X}_{\mathrm{Mg}}$ versus octahedral aluminum content of biotite. (c) Celadonite (Cel) versus muscovite content of white mica. (d) Anorthite $\left(\mathrm{X}_{\mathrm{An}}\right)$ versus albite $\left(\mathrm{X}_{\mathrm{Ab}}\right)$ content of plagioclase as function of microtextural position.

Table S3). The only discrepancies are (i) the presence of minor amounts of chlorite (3.6 vol.\%) at peak conditions, which is possible, but not confirmed by our petrographic observations and (ii) the predicted presence of rutile and absence of ilmenite in the peak assemblage (note that rutile does occur as inclusions in garnet rims). Note that the ilmenite-in reaction curve lies only $0.1 \mathrm{GPa}$ below our peak conditions, which more or less corresponds to the uncertainty on metamorphic reactions of pseudosection modeling in this P-T range (Palin et al., 2016; see also Angiboust \& Harlov, 2017, for further experimental constraints on rutile-forming processes in amphibolite-facies rocks).

Despite uncertainties in the prograde path, the presence of zoisite inclusions in garnet suggests a burial path traversing the zoisite-bearing, amphibole-absent field $\left(\sim 510^{\circ} \mathrm{C}, 0.9 \mathrm{GPa}\right.$; Figure 6). Constraints on the decompression path are based on the following petrographic observations: (i) the increase of the anorthite content of plagioclase toward the rims, (ii) the breakdown of garnet and its replacement by biotite and chlorite, and (iii) the weak chemical zoning of silica in white mica along an exhumation path following the same $\mathrm{Si}$ isopleth. The good preservation of the peak metamorphic assemblage suggests that deformation/ recrystallization ceased relatively early in the exhumation history, probably when the rock entered the greenschist facies $\left(\sim 500{ }^{\circ} \mathrm{C}\right)$. This statement is confirmed by the absence of titanite rims around ilmenite and by the good preservation of garnet porphyroblasts in the studied samples.

\section{3. $\mathrm{Rb}$-Sr and ${ }^{40} \mathrm{Ar} /{ }^{39} \mathrm{Ar}$ Ages}

\subsubsection{Harold Creek}

$\mathrm{Rb}$-Sr mineral data for SCMY1 are available in Ring et al. (2017). For comparison with the new results for samples SCMY2, GC5, GC6, and WAI (Table S4), we summarize the data here (Figure 7a). Regression of the Rb-Sr mineral data of SCMY1 provides an age of $13.1 \pm 4.3 \mathrm{Ma}$. There are Sr-isotopic disequilibria, expressed by pronounced systematic correlations between white-mica grain sizes and $\mathrm{Rb}$-Sr isotopic signatures, with older apparent ages for bigger muscovite grains. Such correlations may result from three different scenarios: (1) The grain-size sensitivity of several ductile deformation mechanisms (Platt \& Behr, 2011) may lead to partial preservation of larger grains as textural relics, like mica fish and feldspar augen. This is in particular the case if deformation is weak and nonpervasive and prolonged in time. Textural relics commonly also show isotopic inheritance (Villa, 2010), explaining the older apparent ages for larger muscovite grains. (2) Textural relics may also be preserved as a result of metamorphic, fluid-present, dissolutionreprecipitation processes (Hyppolito et al., 2019; Putnis, 2009; Villa, 2016). Such processes commonly start 


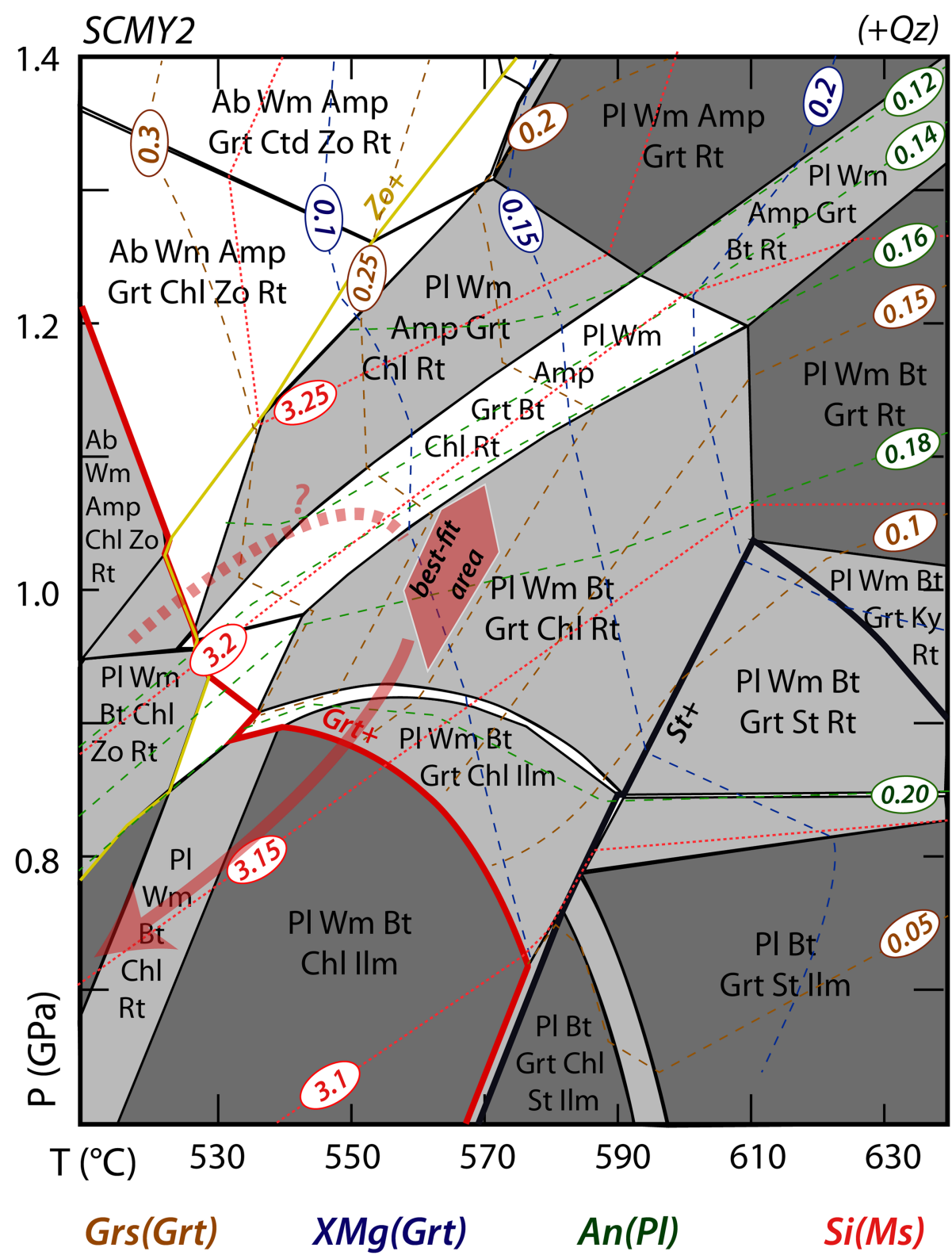

Figure 6. Modeled P-T pseudosection showing topology for SCMY2; P-T path marked by red arrow and best fit area of peak P-T by red polygon. Garnet $\mathrm{X}_{\mathrm{Mg}}\left(=\mathrm{Mg} /\left(\mathrm{Mg}+\mathrm{Fe}^{2+}\right)\right)$ and grossular $(\mathrm{Grs})$ content, anorthite (An) content of plagioclase (Pl), and isopleths showing silica ( $\mathrm{Si}$ ) content of muscovite (Ms) shown.

from grain boundaries or cracks in minerals, again favoring preservation of larger grains as relics during later fluid-controlled overprinting. (3) A correlation between grain size and apparent age may arise from temperature-controlled diffusional $\mathrm{Sr}$ exchange processes during cooling, with more efficient $\mathrm{Sr}$ exchange (or Sr loss) from small grains because of smaller effective diffusion grain radii. However, peak metamorphic temperatures of SCMY1 are $560-570{ }^{\circ} \mathrm{C}$, and $\mathrm{Sr}$ diffusion in white mica is activated to significant extents only at or above $600{ }^{\circ} \mathrm{C}$ (Glodny et al., 1998; Heri et al., 2014). Hence, postpeakmetamorphic, temperature-controlled diffusional exchange between white mica and its matrix is unlikely. The mylonitic texture of the rock indicates that ductile deformation was the last process that caused recrystallization of white mica in the rock. Dynamic recrystallization is well known to reset the $\mathrm{Rb}-\mathrm{Sr}$ system of white mica at temperatures as low as $\sim 300{ }^{\circ} \mathrm{C}$ (Müller et al., 2000; Reddy et al., 2003, and references therein). Textural and microchemical observations provide some indications for minor greenschist-facies fluid driven dissolution-reprecipitation and mineral-reaction processes, like occasional 

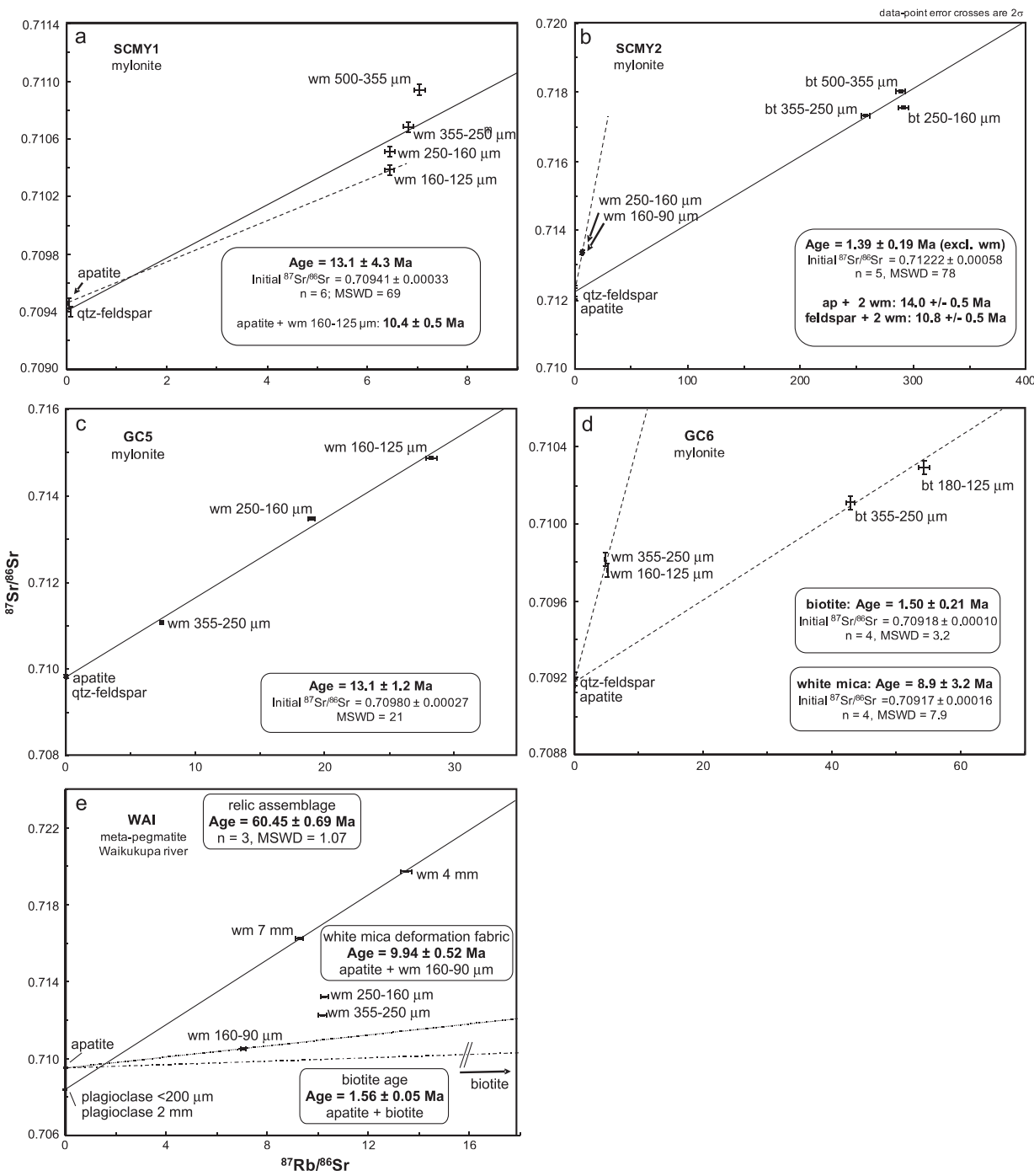

Figure 7. Rb-Sr isochron diagrams for samples SCMY1 (a), SCMY2 (b), GC5 (c), GC6 (d), and WAI (e).

celadonite-enriched rims around muscovite, sporadic partial chloritization of biotite and garnet, and the presence of fine-grained secondary muscovite as reaction products after plagioclase. Therefore, we interpret the white-mica grain size versus apparent age correlation as resulting from protracted, slowly waning deformation and synkinematic recrystallization, potentially combined with minor effects of postmylonitic greenschist-facies overprint(s), like the formation of celadonite rich rims on white mica (Angiboust et al., 2018). The strongest impact of these retrograde processes is expected for the smallest white-mica grains and for low-Rb/Sr phases with low shear strength and susceptibility for fluid-driven recrystallization, like apatite (Engvik et al., 2009; Kusebauch et al., 2015). The apparent apatite-white mica age for the smallest studied grain-size fraction $(160-125 \mu \mathrm{m})$ of $10.4 \pm 0.5 \mathrm{Ma}$ (Figure $7 \mathrm{a}$ ) can thus be regarded as a maximum age for the end of deformation and fluid-driven overprint. Noteworthy, the presence of middle to late Miocene ages between 15 and $10 \mathrm{Ma}$ for $\mathrm{Rb}$-Sr white-mica age signals in this sample is consistent with an extrapolated $100 \% 2 \mathrm{M}$ illite ${ }^{40} \mathrm{Ar} /{ }^{39} \mathrm{Ar}$ age from a nearby fault gouge of 11.46 $\pm 0.47 \mathrm{Ma}$ (Ring et al., 2017).

Sample SCMY2 is a garnet-bearing, biotite-rich mylonite. Indications for low-temperature alteration, like bleaching or chloritization of biotite or chloritization of garnet, are present but rare. $\mathrm{Rb}$-Sr mineral data for feldspar, apatite, and different grain-size fractions of muscovite and biotite show marked Sr-isotopic disequilibria (Figure 7b), namely, between the low- Rb/Sr phases apatite and feldspar and between muscovite 
and biotite. Muscovite $\mathrm{Rb} / \mathrm{Sr}$ data allow calculation of apparent ages of $14.0 \pm 0.5 \mathrm{Ma}$ (apatite + two muscovite grain-size fractions) and $10.8 \pm 0.5 \mathrm{Ma}$ (feldspar + two muscovite grain-size fractions). These middle to late Miocene muscovite-based apparent ages are very similar to the ones obtained from sample SCMY1.

In marked contrast, regression of data for apatite, feldspar, and the three biotite grain-size fractions results in an age value of $1.39 \pm 0.19 \mathrm{Ma}$. This age estimate is somewhat imprecise, due to the apatite versus feldspar disequilibrium and the presence of a minor but significant correlation between biotite grain size and apparent ages, with the oldest apparent age (equivalent to position of mineral-fraction data above the regression line) for the largest grain-size fraction $(500-355 \mu \mathrm{m})$.

For SCMY2, we also analyzed ${ }^{40} \mathrm{Ar} /{ }^{39} \mathrm{Ar}$ signatures of several muscovite and biotite grain-size fractions (Figure 8 and Table S5). Muscovite plateau ages are 2.09 $\pm 0.10 \mathrm{Ma}$ (muscovite 250-160 $\mu \mathrm{m}$ ) (Figure 8a) and $1.38 \pm 0.13 \mathrm{Ma}$ (muscovite 160-90 $\mu \mathrm{m}$ ) (Figure $8 \mathrm{~b}$ ). Biotite plateau ages appear to be slightly younger, with ages for two aliquots of $0.87 \pm 0.11 \mathrm{Ma}$ (Figure 8c) and $1.06 \pm 0.31 \mathrm{Ma}$ (biotite 500-355 $\mu \mathrm{m}$ ) (Figure 8d) and $1.04 \pm 0.17 \mathrm{Ma}$ (biotite $250-160 \mu \mathrm{m}$ ) (Figure 8e). Muscovite shows positive grain-size versus apparent-age correlation, whereas for biotite, such a correlation is not evident.

Comparison between $\mathrm{Rb}-\mathrm{Sr}$ and ${ }^{40} \mathrm{Ar} /{ }^{39} \mathrm{Ar}$ results reveals that the biotite-based $\mathrm{Rb}-\mathrm{Sr}$ and ${ }^{40} \mathrm{Ar} /{ }^{39} \mathrm{Ar}$ age results overlap, with a tendency for younger ages recorded in the ${ }^{40} \mathrm{Ar} /{ }^{39} \mathrm{Ar}$ data. In contrast, $\mathrm{Rb}-\mathrm{Sr}$ muscovite-based apparent ages are considerably older (middle to late Miocene) than ${ }^{40} \mathrm{Ar} /{ }^{39} \mathrm{Ar}$-based muscovite ages (early Pleistocene). Obviously, the Miocene Rb-Sr age signature of muscovite persisted through a process that caused complete (or almost complete) reset of the $\mathrm{K}$-Ar decay system in that mineral and that also caused complete reset of the $\mathrm{Rb}$-Sr age in biotite. The observed age pattern is consistent with cooling of the rock through greenschist-facies conditions in early Pleistocene times in the presence of intergranular fluids. This cooling started from temperatures above the closure temperature for diffusive Ar loss from muscovite (near 450 to $500{ }^{\circ} \mathrm{C}$ for muscovite, grain size 100-200 $\mu \mathrm{m}$, open-system conditions; Warren et al., 2012) at about $2 \mathrm{Ma}$, down to temperatures of closure of the $\mathrm{K}$-Ar system in biotite (near $350{ }^{\circ} \mathrm{C}$, Harrison \& McDougall, 1985). Textural observations in sample SCMY2 (see above) include evidence for costability of muscovite and biotite in the main mylonitic foliation. Mylonitic, foliation-forming ductile deformation is known to easily reset the Rb-Sr signatures of muscovitic white mica at temperatures as low as $\sim 300{ }^{\circ} \mathrm{C}$ (see above). Given that Miocene Rb-Sr muscovite ages are preserved, we conclude that the last fabricdefining ductile deformation in the sample occurred at about 14 to $10 \mathrm{Ma}$ and that Rb-Sr biotite, as well as ${ }^{40} \mathrm{Ar} /{ }^{39} \mathrm{Ar}$ muscovite and biotite ages, record cooling under static conditions. This is consistent with the preservation of the peak metamorphic assemblage indicating that deformation in the amphibolite-facies mylonite stopped relatively early in the exhumation and cooling history of the rock.

\subsubsection{Gaunt Creek}

Sample GC5 is a garnet-bearing, feldspar-muscovite-rich mylonite, with minor biotite. Indications for low-temperature alteration are virtually absent. From the fabric-forming assemblage of muscovite, feldspar, and apatite, we obtain a fairly well-defined $\mathrm{Rb}$-Sr multimineral age of $13.1 \pm 1.2 \mathrm{Ma}$ (Figure 7c) (Table S4). There is no significant contrast between the apparent ages for different muscovite grain-size fractions, indicating that neither isotopic relics nor diffusion-driven resetting affected $\mathrm{Rb}$-Sr signatures in the muscovite population in this sample. Given the strong mylonitic fabric in the rock, the age is best interpreted as dating the end of mylonitic deformation at amphibolite-facies conditions in the stability field of garnet.

Sample GC6 is a garnet-bearing mylonite. Muscovite $\mathrm{Rb}-\mathrm{Sr}$ and ${ }^{40} \mathrm{Ar} /{ }^{39} \mathrm{Ar}$ age analyses have already been reported by Ring et al. (2017). Muscovite Rb-Sr data (Figure 7d) show a similar pattern to that of sample SCMY2 (Figure 7b). The data show disequilibrium, with a slightly younger apparent age for the more finegrained muscovite fraction. In combination with mineral data for quartz-feldspar and apatite, an apparent white-mica age of $8.9 \pm 3.2 \mathrm{Ma}$ is obtained, demonstrating the presence of middle to late Miocene white mica in this sample.

Two biotite grain-size fractions were also analyzed from GC6 (Figure 7d). These two biotite fractions combined with apatite and feldspar yield an early Pleistocene age of $1.50 \pm 0.21 \mathrm{Ma}$. There is a (hardly significant) tendency of the smaller biotite grain-size fraction toward a younger age. In combination with the Miocene muscovite age and the observation of textural equilibrium between biotite and muscovite, this 

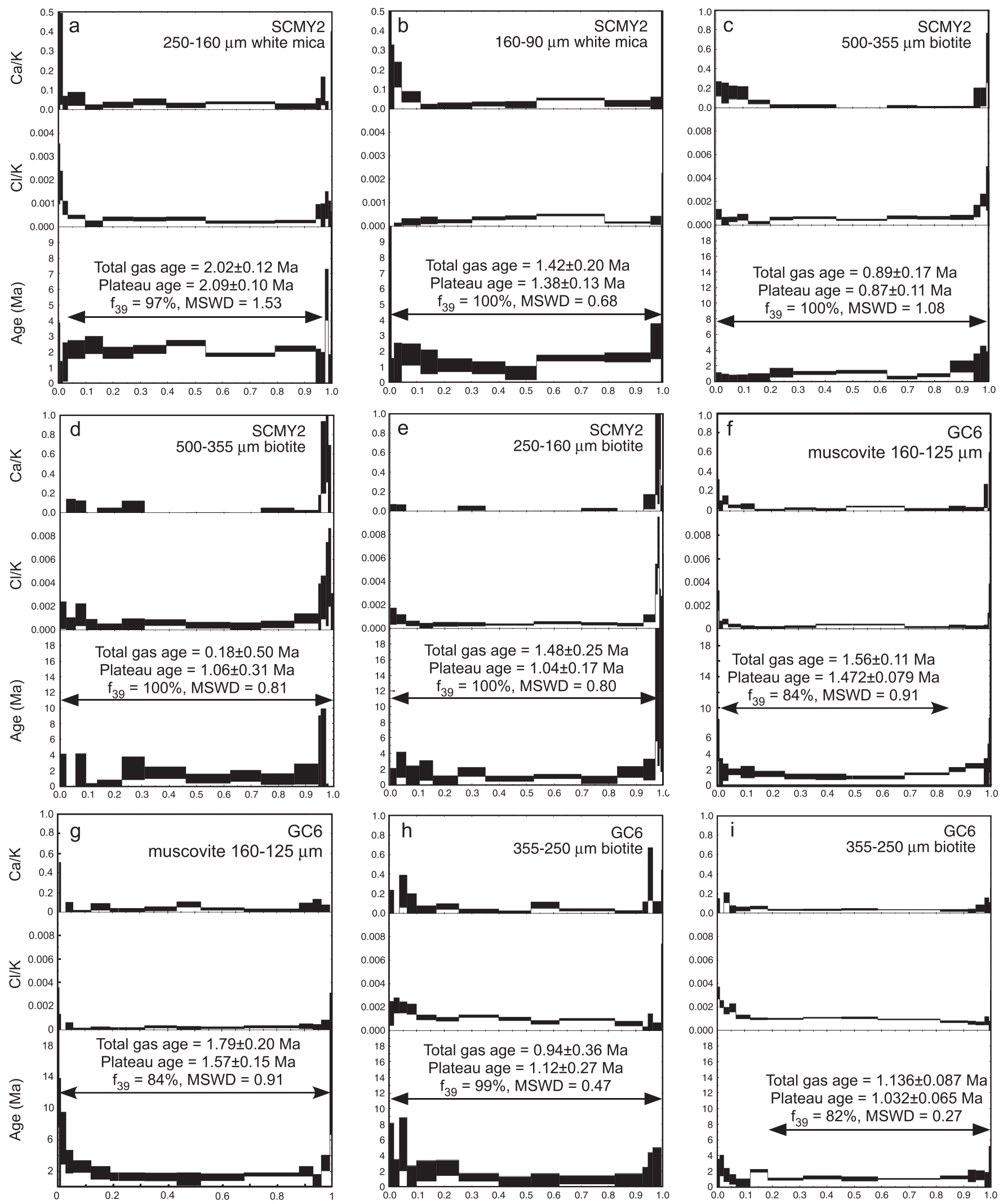

Fraction of ${ }^{39} \mathrm{Ar}$ released

Figure 8. ${ }^{40} \mathrm{Ar} /{ }^{39} \mathrm{Ar}$ age spectra for different grain-size fractions of muscovite and biotite from samples SCMY2 (a-e) and GC6 (f-i). 
Pleistocene age suggests that the biotite $\mathrm{Rb}$-Sr age was reset during cooling, at largely static, fluid-present, open-system, greenschist-facies conditions.

The ${ }^{40} \mathrm{Ar} /{ }^{39} \mathrm{Ar}$ plateau ages for two aliquots of the muscovite $160-125 \mu \mathrm{m}$ grain-size fraction from that sample are $1.47 \pm 0.08$ and $1.57 \pm 0.15 \mathrm{Ma}$ (Figures $8 \mathrm{f}$ and $8 \mathrm{~g}$ and Table S5), that is, they are identical within uncertainties. We also analyzed in duplicate the $355-250 \mu \mathrm{m}$ grain-size fraction of biotite for ${ }^{40} \mathrm{Ar} /{ }^{39} \mathrm{Ar}$. Plateau ages of $1.12 \pm 0.27 \mathrm{Ma}$ and $1.03 \pm 0.07 \mathrm{Ma}$ (Figures $8 \mathrm{~h}$ and $8 \mathrm{i}$ ) appear slightly younger than the muscovite ${ }^{40} \mathrm{Ar} /{ }^{39} \mathrm{Ar}$ ages and also slightly younger that the $\mathrm{Rb}$-Sr based biotite age but are statistically indistinguishable from them within limits of uncertainty. Similar to sample SCMY2, biotite Rb-Sr and K-Ar isotope systems of both muscovite and biotite closed during an episode of rapid cooling in the early Pleistocene.

\subsubsection{Waikukupa River}

Sample WAI is a garnet-bearing micaschist containing a remarkably coarse-grained muscovite + feldspar subassemblage (with muscovite crystals up to $1 \mathrm{~cm}$ in diameter) in a fine-grained matrix of feldspar, quartz, biotite, apatite, and minor carbonate. The texture of this rock, particularly the bimodal grain-size distribution of feldspar and muscovite, reflects its content of strongly deformed metapegmatite veins, as described for this site by Norris and Cooper (2003). In this rock, light-colored, coarse-grained, muscovite-bearing quartzofeldspathic layers represent deformed pegmatites of granitic composition that experienced amphibolite-facies ductile shearing. In such rocks, the textural relic assemblage may provide age information on primary melt crystallization (cf. Eberlei et al., 2015; Glodny et al., 1998). We therefore analyzed multiple muscovite fractions, including two large, seemingly undeformed muscovite porphyroclasts and one augen-type feldspar crystal, apatite, and biotite for Rb-Sr signatures.

Minerals from the primary, pegmatitic subassemblage (two different white-mica porphyroclasts + augen feldspar) provide an isochron age of $60.45 \pm 0.69 \mathrm{Ma}$ (Figure 7e) (Table S4). Given the high retentivity of pegmatitic white mica "books" for Rb-Sr even at temperatures $>600{ }^{\circ} \mathrm{C}$ (Glodny et al., 1998), this age is interpreted as dating crystallization of the pegmatitic assemblage from a melt. $\mathrm{Rb}$ concentrations in muscovite $(<258 \mathrm{ppm})$ and ${ }^{87} \mathrm{Rb} /{ }^{86} \mathrm{Sr}$ ratios $(<13.5)$ are much lower than values characteristic for evolved granitic rare-element pegmatites (cf. Küster, 1995). We therefore hypothesize that the pegmatite was formed by primary anatectic minimum melts during a high-T migmatite stage at about 60 Ma.

Fine-grained white-mica grain-size fractions show a pronounced positive correlation between grain size and apparent ages (Figure 7e). Larger grain-size fractions potentially are mixtures between partially relic "pegmatitic" muscovite and fully recrystallized, deformation-related muscovite. Assuming that the finest muscovite fraction is least affected by partial inheritance, the apparent age of $9.94 \pm 0.52 \mathrm{Ma}$ for apatite and the muscovite grain-size fraction of 160-90 $\mu \mathrm{m}$ can be regarded as a maximum age for the end of (Miocene) ductile deformation.

Biotite forms part of the deformation-related subassemblage and thus was present in the rock already when ductile deformation largely ceased in Miocene times. Yet the apparent $\mathrm{Rb}-\mathrm{Sr}$ age for the biotite is reset to 1.56 $\pm 0.05 \mathrm{Ma}$ (calculated using biotite and apatite data; Figure 7e). As for other samples, we interpret this age as dating a stage of greenschist-facies cooling.

\subsection{Summary of Geochronologic Data}

Before discussing the orogen-scale implications of our new data, we summarize the geochronologic data. The first recorded event is a stage of primary melt crystallization at about $60 \mathrm{Ma}$ (sample WAI). Vry et al. (2004) also reported a Rb-Sr plagioclase-hornblende-whole rock isochron age of $86.2 \pm 2.3 \mathrm{Ma}$ from the same locality (their sample 4). This age is supported by a Rb-Sr garnet-whole rock isochron age of $86.2 \pm 11 \mathrm{Ma}$ from Moeraki River (Figure 1) (their sample 5).

Because muscovite codefines the mylonitic fabric in the studied Alpine Schist samples and mylonitic deformation is known to easily reset $\mathrm{Rb}-\mathrm{Sr}$ signatures of muscovitic white mica, we infer that the last phase of the ductile mylonitic fabric developed at peak amphibolite-facies metamorphic conditions $\left(\sim 560-570{ }^{\circ} \mathrm{C}\right.$ and $\sim 0.9-1.1 \mathrm{GPa}$ ). The most robust age is recorded in sample GC5 at $13.1 \pm 1.2 \mathrm{Ma}$, calculated from a fairly unambiguous regression line, and validated by the absence of a correlation between grain size and apparent age for different muscovite grain-size fractions. Overall, most Rb-Sr muscovite ages are not well defined and overlap at about 14-10 Ma with a weighted mean age of $10.74 \pm 0.57 \mathrm{Ma}$ (Figure 9). A weighted mean age of $10.74 \pm 0.57 \mathrm{Ma}$ is within uncertainty similar to the ${ }^{40} \mathrm{Ar} /{ }^{39} \mathrm{Ar}$ illite/mica upper-intercept age of $11.46 \pm 0.47$ 


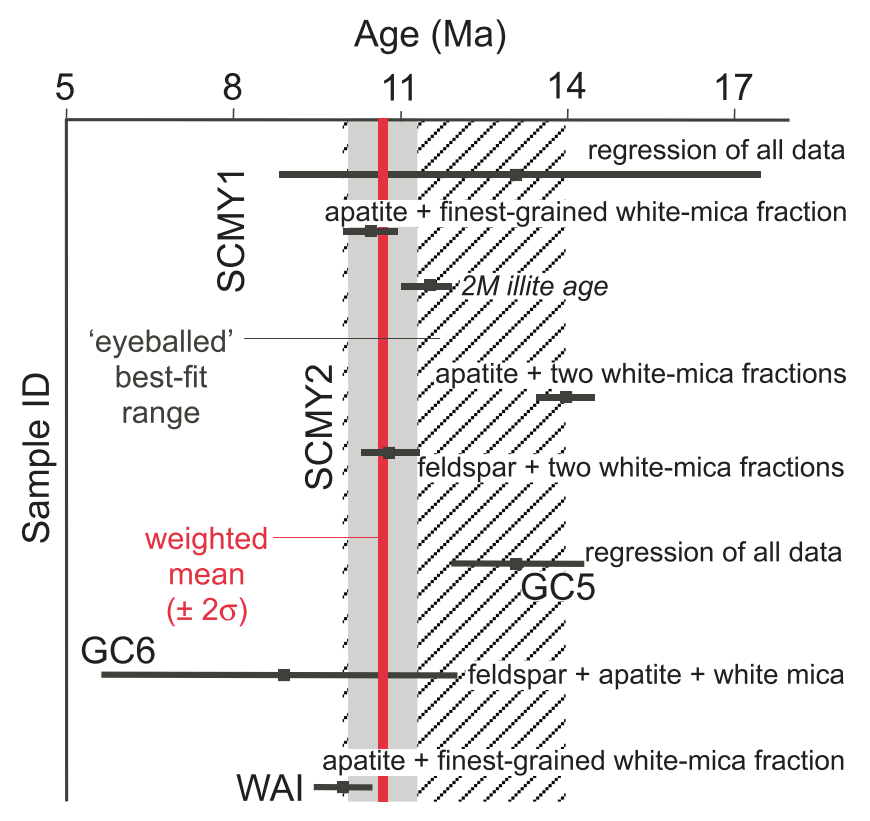

Figure 9. Summary of $\mathrm{Rb}-\mathrm{Sr}$ white-mica-based multimineral age data; $2 \mathrm{M}$ illite ${ }^{40} \mathrm{Ar} /{ }^{39} \mathrm{Ar}$ age from Ring et al. (2017) with calculated weighted mean age of all data for end of mylonitic shearing and "visually" estimated best fit range of age data.
Ma reported in Ring et al. (2017). The $10.74 \pm 0.57 \mathrm{Ma}$ is arithmetically correct, but we consider a spread of ages between 14 and 10 Ma geologically more reasonable.

Muscovite ${ }^{40} \mathrm{Ar} /{ }^{39} \mathrm{Ar}$ ages are between $\sim 2.1$ and $\sim 1.4 \mathrm{Ma}\left(\sim 500 / 450{ }^{\circ} \mathrm{C}\right)$ and biotite ${ }^{40} \mathrm{Ar} /{ }^{39} \mathrm{Ar}$ ages are between $\sim 1.1$ and $\sim 0.9 \mathrm{Ma}\left(\sim 350{ }^{\circ} \mathrm{C}\right)$. There are also biotite $\mathrm{Rb}$-Sr ages between $\sim 1.56$ and $\sim 1.39 \mathrm{Ma}$ (samples SCMY2, GC6, and WAI). The discrepancy between these Pleistocene ages and the Miocene $\mathrm{Rb}-\mathrm{Sr}$ muscovite ages indicates that the K-Ar muscovite system in the samples was not synkinematically reset in the Pleistocene. The nature of muscovite indicates synkinematic muscovite formation or reworking so that the Miocene $\mathrm{Rb}-\mathrm{Sr}$ muscovite ages are best interpreted as deformation and/or growth ages, whereas the Pleistocene age signals are best interpreted as cooling ages (cf. Egli et al., 2016). It follows that ${ }^{40} \mathrm{Ar} /{ }^{39} \mathrm{Ar}$ white-mica ages, as well as $\mathrm{Rb}$-Sr biotite and ${ }^{40} \mathrm{Ar} /{ }^{39} \mathrm{Ar}$ biotite ages, are consistent with rapid cooling from $\sim 500 / 450$ to $\sim 350{ }^{\circ} \mathrm{C}$ at largely static conditions in our samples. To interpret the latter ages as cooling ages, open-system conditions and the presence of fluids are required to facilitate efficient removal or redistribution of radiogenic Sr and Ar (cf. Glodny et al., 2003; Smye et al., 2013). Indeed, there is evidence for lower-greenschist-facies fluid activity in the rocks, like partial chloritization of biotite and garnet or sericitization of plagioclase. Despite this late fluid infiltration, some white mica ${ }^{40} \mathrm{Ar} /{ }^{39} \mathrm{Ar} \mathrm{K}$-Ar signatures are still recording the late stages of ductile deformation (metamorphic white mica age of $11.46 \pm 0.47 \mathrm{Ma}$ from fault gouge reported by Ring et al., 2017), a fact that may indicate a nonpervasive nature of Pleistocene fluid percolation through the analyzed samples.

\section{Discussion}

Our results indicate that the end of mylonitic shearing at peak amphibolite-facies metamorphic conditions in the Alpine Schist occurred in the middle to late Miocene. The peak metamorphic conditions show that the crust had been thickened by that time and thus supported high topography. Additionally, consistently young Pleistocene ages of 2-1 Ma indicate that Alpine Schist mylonite has experienced a two-phase history since 14-10 Ma, with the young phase of rapid cooling recording the final "conveyor belt" ascent of the hanging-wall rocks of the Alpine fault (Figure 10a). The $~ 60$ Ma age for pegmatite crystallization from sample WAI shows another high-temperature event in the earliest Tertiary. This $\sim 60 \mathrm{Ma}$ age is younger than most of the hitherto reported Late Cretaceous ages for this high-temperature event.

\subsection{Crustal Thickening in the Middle to Late Miocene}

Vry et al. (2004) summarized the difficulties of successfully dating the growth of high-temperature metamorphic minerals in the Alpine Schist, which include (1) the absence of magmatic rocks containing zircon and the absence of monazite (Batt et al., 1999; Chamberlain et al., 1995; Mortimer \& Cooper, 2004), (2) the lack of sufficient $\mathrm{U}$ and radiogenic $\mathrm{Pb}$ for $\mathrm{U}-\mathrm{Pb}$ or $\mathrm{Pb}-\mathrm{Pb}$ dating of titanite (Mortimer \& Cooper, 2004), and (3) the small size, inclusion-rich nature, and in many cases complex overgrowth history of most high-grade minerals including garnet. As mentioned above, nucleation enhancement and growth kinetics in fluidsaturated mylonitic rocks may overcome at least some of these impediments. This is demonstrated, for instance, by the simple, chemical zoning pattern and internal structure of the synkinematic, one-phase garnet crystals we selected to study (Figures 3e-3h). Furthermore, elsewhere, Rb-Sr muscovite-based multimineral isochron dating proved to be a successful technique for dating amphibolite- and eclogite-facies metamorphic rocks that show no or only weak subsequent overprinting (Eberlei et al., 2015; Glodny et al., 2005; Glodny et al., 2008; Reddy et al., 2003; Ring, Glodny, et al., 2018; Schulte et al., 2014).

Our muscovite-based $\mathrm{Rb}$-Sr ages are the first to constrain the end of Neogene amphibolite-facies mylonitic shearing in the currently exposed Alpine Schist. Our P-T data indicate that the mylonitization event took place at $560-570{ }^{\circ} \mathrm{C}$ and $0.9-1.1 \mathrm{GPa}(33-41 \mathrm{~km}$ depth), which is similar to peak P-T of the Alpine Schist of $580-620^{\circ} \mathrm{C}$ and $1-1.15 \mathrm{GPa}(37-45 \mathrm{~km}) \sim 100 \mathrm{~km}$ further north (Vry et al., 2004). These P-T conditions 

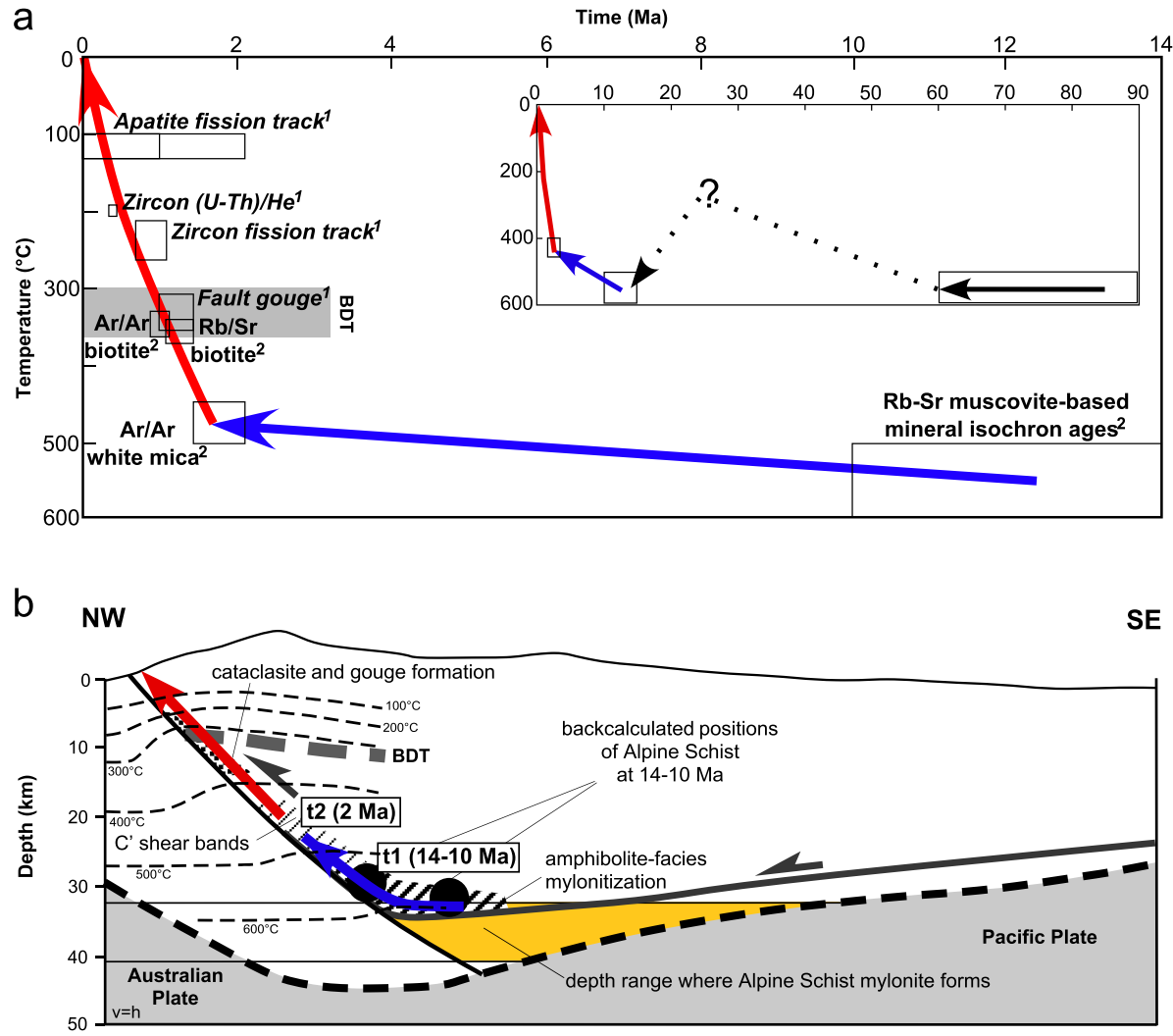

Figure 10. (a) Temperature-time (T-t) diagram derived from age dating in currently exposed Alpine Schist mylonite (zircon fission track and (U-Th)/He ages and apatite fission track ages (all italics) from Ring et al., $2017^{1}$ ) and all other data from this study ${ }^{2}$; T-t data indicate slow cooling between $\sim 14-10$ and $\sim 2 \mathrm{Ma}$; solid blue line reflects time-averaged cooling rates of $\sim 10^{\circ} \mathrm{C} / \mathrm{Myr}$. Inset shows extended T-t path including Late Cretaceous/early Tertiary data from Vry et al. (2004) (Lu-Hf on garnet), Scott et al. (2015) (U-Pb on monazite), Briggs et al. (2018) (Lu-Hf on garnet), and this study (Rb-Sr age of $60 \mathrm{Ma}$ from sample WAI). Stippled path virtually unconstrained showing cooling of Cretaceous high-T rocks until onset of dextral transpression in Southern Alps in early Miocene. (b) Interpretation of two-stage T-t history. Alpine Schist mylonite formed approximately where décollement would hit Alpine Fault ramp (note that existence of décollement at 14-10 Ma uncertain), black dots indicate estimated positions of mylonite based on exhumation rates (discussed in text) and age of mylonitization of 14-10 Ma; isotherms according to Toy et al. (2010). Slow cooling from t1 and t2 between widely spaced isotherms. Note that position of mylonite at $14 \mathrm{Ma}$ allows for initial movement subparallel to isothermal structure, which may better explain T-t path. BDT $=$ brittle-ductile transition zone.

attest to a thickened crust. A reasonable approximation of the crustal thickness at the Oligocene/Miocene boundary is $\sim 25 \mathrm{~km}$ (Walcott, 1998) as inferred from preorogenic crust in places like the Canterbury Basin and shallow marine sedimentation at that time. Despite some Sr-isotopic disequilibria, our data provide a robust minimum age constraint on the timing of $\sim 10-15 \mathrm{~km}$ of crustal thickening. The middle to late Miocene crustal thickness was thus largely similar to today's thickness.

Ages of about 14-10 Ma for the end of ductile shearing are consistent with the inferred age of outermost garnet rims overgrowing the mylonite fabric (Vry et al., 2004), which should be of the order of $15 \mathrm{Ma}$ (see above for discussion of this age using exhumation rates of Kamp et al., 1989). The ages for the end of ductile fabric development in Alpine Schist mylonite are distinctly older than hitherto envisaged and indicate that crustal thickening in the Southern Alps started before 14-10 Ma. Based on apatite fission track ages in the Bonar Range in the footwall of the Alpine Fault, Ring and Bernet (2010) similarly proposed that transpressional crustal thickening and associated rock uplift was underway by $11 \mathrm{Ma}$. Palinspastic restorations in the footwall (foreland) of the northern Alpine Fault demonstrate that reverse reactivation of preexisting steep faults, which were mostly blind, started at ca. $22 \mathrm{Ma}$. Hiatuses and unconformities at 17-10 Ma reflect the propagation of high-angle reverse basement faults to the surface since the middle Miocene (Ghisetti et al., 2016). Regional hiatuses and unconformities at 17-10 Ma have also been documented by King et al. (1999). In 
the middle Miocene, sufficient topography had developed to subside the lithosphere along the plate boundary, generating a foreland basin west of the Alpine Fault (Sircombe \& Kamp, 1998). ${ }^{13} \mathrm{C}$ excess measurements from middle Miocene lacustrine deposits in central Otago suggest this early topography may have attained at least $1.5 \mathrm{~km}$ of relief (Horton et al., 2016). Increased topography may explain Miocene highenergy conglomerate deposition in the Maruia Basin (Cutten et al., 2006). Lu and Fulthorpe (2004) showed increased sedimentation rates in the middle Miocene in the Canterbury basin to the east of the Southern Alps. Collectively, all data indicate that crustal shortening in the Southern Alps and the formation of a thick crustal root was underway by $14-10 \mathrm{Ma}$ and supported increased topography of a growing Southern Alps since the middle Miocene.

\subsection{Rapid Cooling in Pleistocene}

The next geochronologic record in Alpine Schist mylonite after the end of peak metamorphic conditions and mylonitic shearing at $\sim 14-10 \mathrm{Ma}$ are the ${ }^{40} \mathrm{Ar} /{ }^{39} \mathrm{Ar}$ white mica and biotite ages and the Rb-Sr biotite-based ages of $\sim 2.1$ to $\sim 0.9 \mathrm{Ma}$. We interpret the $\sim 2.1$ to $\sim 0.9 \mathrm{Ma}$ ages to reflect cooling from $500 / 450{ }^{\circ} \mathrm{C}$ through 350 ${ }^{\circ} \mathrm{C}$ (Figure 10a).

If our interpretation of these ages as cooling ages was accepted, it follows that temperatures were probably in the stability field of garnet (greater than $\sim 450^{\circ} \mathrm{C}$ ) but below the temperatures required to reset $\mathrm{Rb}$-Sr in muscovite $\left(>600{ }^{\circ} \mathrm{C}\right)$ for the period between $\sim 14-10$ and $\sim 2 \mathrm{Ma}$. The $\sim 2.1$ to $\sim 0.9 \mathrm{Ma}$ ages would indicate cooling from $500 / 450{ }^{\circ} \mathrm{C}$ through $350{ }^{\circ} \mathrm{C}$ at time-averaged rates exceeding $100{ }^{\circ} \mathrm{C} / \mathrm{Myr}$. Similar and even more rapid cooling rates have already been proposed by Holm et al. (1989), Kamp et al. (1989), Batt et al. (2000), Little et al. (2005), and Ring et al. (2017). The geothermal gradient is very high and the brittle-ductile transition shallow ( $\leq 10 \mathrm{~km}$, Leitner et al., 2001). The presently exposed Alpine Schist was at the verge from amphibolite- to greenschist-facies conditions at about $2 \mathrm{Ma}\left(450-500^{\circ} \mathrm{C}\right.$, depending on the envisaged closure temperature for Ar diffusion in white mica) (Figure 10a). Due to the preservation of Miocene muscovite Rb$\mathrm{Sr}$ ages, Pleistocene ductile deformation can be ruled out for our amphibolite-facies mylonite samples. However, because temperatures above $300-350{ }^{\circ} \mathrm{C}$ usually envisaged for the brittle-ductile transition lasted until $\sim 1 \mathrm{Ma}$, ductile shearing is likely to have contributed to the exhumation of mylonitic rocks in the Pleistocene. The shear fabrics preserved in ultramylonite, mylonite, and cataclasite indicate dextral-reverse slip (Little et al., 2002; Norris \& Cooper, 2007; Toy et al., 2008) accordant with the known, present-day slip kinematics of the Alpine Fault. We envisage that the Pleistocene exhumation of the currently exposed mylonite was mostly absorbed in the more fault-proximal, localized ultramylonite zone within a few tens of meters of the Alpine Fault and in the fault-distal part of the Alpine mylonite zone where $\mathrm{C}^{\prime}$ shear bands are pervasively developed. In the ultramylonite zone, garnet is more thoroughly chloritized (Figures 3a3d) than in our dated samples and (upper)greenschist-facies deformation and subsequent cataclastic deformation and fault gouge formation occurred. In other words, deformation associated with rapid cooling and exhumation was partitioned into this narrow zone, especially the cataclasite/gouge zone immediately above the Alpine Fault.

The white-mica closure temperature for the K/Ar system was probably at depths of 10-12 $\mathrm{km}$ (if a $\sim 40-50^{\circ}$ $\mathrm{C} / \mathrm{km}$ thermal gradient [see above] was used). This depth estimate results in minimum averaged exhumation rates of $\sim 5-6 \mathrm{~km} / \mathrm{Myr}$ since $\sim 2 \mathrm{Ma}$. These exhumation rates are controlled by rapid erosion and similar to rates reported by Kamp et al. (1989) for the period from $\sim 1$ Ma to the present. The rocks above the décollement are moving rapidly westward with a translation component normal to the Alpine Fault of 6$9 \mathrm{~km} / \mathrm{Myr}$ (Beavan et al., 2002), which is similar to current erosion-controlled exhumation rates on the west side of the Southern Alps (Hovius et al., 1997; Simpson et al., 1994). Numerical models of the coupling between orogen deformation and orographic precipitation predict that the horizontal displacement rates match exhumation rates (Willett et al., 1993). Surface processes that erode mountain belts lead to large-scale removal of mass and cause the velocity field to adjust to replace eroded material by material from within, requiring that deformation adjusts to replace removed material (Willett et al., 1993). Rapid erosion and associated heat advection also control the "modern" high conductive thermal gradient (Batt et al., 2000; Craw, 1997; Holm et al., 1989; Ring et al., 2017). An age of 2 Ma would be a minimum age for the establishment of the midcrustal décollement and the "conveyor belt." This is a minimum age as there may have been (now eroded) Alpine Schist mylonite that had rapidly cooled and exhumed prior to $2 \mathrm{Ma}$ (see also below). 


\subsection{Interpretation of Temperature-Time History}

The T-t path for the exhumed Alpine Schist mylonite shows slow cooling of about $10^{\circ} \mathrm{C} / \mathrm{km}$ from $\sim 14$ to 10 Ma until $\sim 2 \mathrm{Ma}$ (Figure 10a). A pre-2 Ma exhumation rate is less well constrained but would be of the order of 2 to $<4 \mathrm{~km} / \mathrm{Myr}$ (exhumation from 33-41 km at 14-10 Ma to 10-12 km at about $2 \mathrm{Ma}$ ) and again similar to the rates of Kamp et al. (1989) between $~ 5.5$ and 1 Ma. Batt et al. (2004) and Lang et al. (2018) argue for slow Miocene exhumation rates during the interval between $\sim 20$ and $\sim 8 \mathrm{Ma}$. The combination of crustal thickening and slow exhumation supports the argument made above that the Southern Alps was growing during the Miocene.

The differences in exhumation and cooling rates indicate a change at $\sim 2 \mathrm{Ma}$. However, the change at $\sim 2 \mathrm{Ma}$ is only valid for the currently exposed Alpine Schist mylonite. Older, eroded mylonite could have potentially seen the same change before $2 \mathrm{Ma}$. The occurrence of Alpine Schist detritus in sediments in the Waiho-1 drill core suggests that conditions similar to the present-day ones were already established prior to $4 \mathrm{Ma}$ (Sutherland, 1996) and as early as 8-7 Ma (Batt et al., 2004; Lang et al., 2018; Tippett \& Kamp, 1993). Therefore, we speculate that on the scale of the Southern Alps, the change depicted in the T-t curve first occurred by 8-7 Ma and that 8-7 Ma marks the time when the modern "conveyor belt" formed.

The envisaged depth of the décollement is $\sim 35 \mathrm{~km}$, a depth largely based on P-T estimates of exposed Alpine Schist (Figure 10b). Such a proposition would be in line with the commonly held opinion that structures and kinematics of Alpine Schist mylonite reflect Alpine Fault motion. This linkage and the Alpine Fault origin of the Alpine Schist mylonite zone have been proposed by many workers (e.g., Norris \& Cooper, 2003, 2007; Sibson et al., 1981) on the basis of high finite shear strains in the Alpine mylonite zone and quartz latticepreferred orientations in those rocks that record amphibolite-facies conditions of ductile shearing. This shear deformation, localized to within $\sim 0.5-1.5 \mathrm{~km}$ of the Alpine Fault, was uniformly dextral-reverse in sense and featured a shearing vector that is indistinguishable from the modern slip direction on the Alpine Fault (Little et al., 2015, 2016; Toy et al., 2008).

Using exhumation rates of $6 \mathrm{~km} / \mathrm{Myr}$ from $2 \mathrm{Ma}$ to the present and $3 \mathrm{~km} / \mathrm{Myr}$ for the time between 14-10 and $2 \mathrm{Ma}$ (see above) and translating those vertical rates into displacement rates along a $45^{\circ}$-dipping Alpine Fault results in total displacements of the Alpine Schist mylonite of $\sim 40-55 \mathrm{~km}$ since its formation (and is broadly in line with plate reconstructions of Furlong \& Kamp, 2009, which require 55-65 km of displacement since 14-10 Ma). These calculations place the position of the currently exposed Alpine Schist at 10 Ma near the point where the décollement hits the Alpine Fault ramp and at $14 \mathrm{Ma}$ along the subhorizontal midcrustal décollement (Figure 10b). Little et al. (2005) inferred that integrated exhumation rates in the hanging wall of the Alpine fault have been slow enough in the Neogene that midcrustal rocks derived from the base of the Alpine fault ramp have still not been exhumed along this structure, except in the most rapidly exhuming, central part of the Southern Alps northwest of Aoraki (Mt Cook), which led them to infer $<60 \mathrm{~km}$ of dip-slip on the fault outside of the that central region, and perhaps only slightly more than that within it.

Our new age data constraining the end of peak metamorphic mylonitic shearing to $14-10$ Ma demonstrate that the currently exposed Alpine Schist mylonite cooled slowly for about 8-12 Myr (Figure 10a). Toy et al. (2010) estimated a strongly nonlinear geothermal gradient of $\sim 40^{\circ} \mathrm{C} / \mathrm{km}$ above the brittle-ductile transition zone and a distinctly lower gradient of $\sim 10^{\circ} / \mathrm{km}$ below the brittle-ductile transition zone. Gradient nonlinearity is due to the vertical advection of heat during rapid exhumation in the Alpine Fault hanging wall (Kidder et al., 2018; Sutherland et al., 2017), and Koons (1987) numerically modeled such a stepped isotherm. We envisage that the Alpine Schist mylonite moved initially (between $\mathrm{t} 1$ and $\mathrm{t} 2$ in Figure 10b) between the more widely spaced isotherms, therefore cooled slowly and also exhumed at a more moderate rate of 2.5-3 km/Myr. At about $2 \mathrm{Ma}$, the mylonite started to move through the more condensed, nearsurface isothermal structure and cooled distinctly more rapidly. At this time, the exhumation rate also increased.

\subsection{Late Cretaceous/Paleogene High-Temperature Metamorphism, Magmatism, and Cooling}

We recorded pegmatite crystallization at about $60 \mathrm{Ma}$ (sample WAI). This event may be consistent with a RbSr plagioclase-hornblende-whole rock isochron age of 86.2 $\pm 2.3 \mathrm{Ma}$ from the same locality (sample 4 of Vry et al., 2004) and a Rb-Sr garnet-whole rock isochron age of 86.2 11 Ma from Moeraki River (sample 5 of Vry et al., 2004) (Figure 1 and inset in Figure 10a). Similar Late Cretaceous to Paleogene ages for metamorphism, 
dike intrusions, and cooling occur in both the Australian and the Pacific Plate concentrated along a thermotectonic corridor close (within $\sim 100 \mathrm{~km}$ ) to the present Alpine Fault (Mortimer, 2018). Given the widely accepted "conveyor belt" model for Neogene mountain building, Pacific Plate rocks are overriding the Australian Plate for about $90 \mathrm{~km}$, thereby narrowing their spatial distribution along the Alpine Fault. Hence, the notion of a Late Cretaceous through Paleogene wider "Alpine Fault thermotectonic corridor" might be an artifact of Neogene transpression. In addition to the Late Cretaceous/Paleogene ages for high-T metamorphism, there are also numerous Cretaceous/Paleogene low-T thermochronologic ages across the South Island (Ring, Mortimer, et al., 2018; Tippett \& Kamp, 1993) and Stewart Island (Reiners et al., 2004; Ring et al., 2015) (Table S6), which have hitherto hardly been considered in compilations for Late Cretaceous/Paleogene ages (Briggs et al., 2018; Cooper \& Palin, 2018; Mortimer, 2018). However, when the lithosphere is deforming, there needs to be deformation compatibility, and ages for lower crustal highgrade metamorphism are linked in some way with low-T thermochronologic ages in the upper crust.

The geochronologic data reflect a spread of Late Cretaceous through Paleogene ages for high-T metamorphism (various $\mathrm{Sm}-\mathrm{Nd}$ and $\mathrm{Lu}-\mathrm{Hf}$ garnet, $\mathrm{U}-\mathrm{Pb}$ monazite, and $\mathrm{U}-\mathrm{Pb}$ zircon, as well as $\mathrm{Rb}-\mathrm{Sr}$ mineral ages between 98 and $50 \mathrm{Ma}$ ), cooling in the brittle crust (fission track, (U-Th)/He, and possibly K-Ar biotite ages of 113-46 Ma), and shallow level dike intrusions at 98-68 Ma. Ages reflecting high-T metamorphism occur in the direct hanging wall of the Alpine Fault. The low-T thermochronologic ages in the Pacific Plate occur far away from the Alpine Fault. In contrast, Cretaceous fission track (Ring \& Bernet, 2010) and K-Ar biotite (Rattenbury, 1987) cooling ages occur in close proximity of the Alpine Fault in the Australian Plate. These contrasting patterns reflect the very different exhumation levels of the Neogene to Recent orogeny on either side of the Alpine Fault.

In general, the garnet ages are older than the U-Pb zircon ages. However, ages reflecting deep-seated metamorphism show a similar and large spread as ages for cooling and dike intrusions in the brittle crust. As such, all ages are interpreted to reflect protracted and/or repeated thermotectonic event(s) rather than variably reset ages resulting from a single "old" event at, say, 100-90 Ma. This statement is corroborated by the fact that without severe recrystallization or dissolution/reprecipitation, it is nearly impossible to reset garnet $\mathrm{Lu} / \mathrm{Hf}, \mathrm{Sm} / \mathrm{Nd}$, or U-Pb zircon ages. Lu-Hf dates represent garnet growth (rather than cooling) under prevalent crustal conditions (e.g., Scherer al., 2000), whereas Sm-Nd ages of garnet are only affected by potential partial diffusive resetting at granulite-facies conditions (Smit et al., 2013) and will not be affected to any major extent as long as compositional garnet growth zoning is preserved (Dutch \& Hand, 2010). The U-Pb system of zircon is thermally stable even at temperatures above $900{ }^{\circ} \mathrm{C}$ (Lee et al., 1997).

Protracted metamorphism in the lower crust might be supported by the Rb-Sr ages reported by Vry et al. (2004) and in this study from the same locality at Waikukupa River. The Vry et al. (2004) Rb-Sr plagioclase-hornblende-whole rock isochron age of $86.2 \pm 2.3 \mathrm{Ma}$ is from a garnet-bearing mafic rock, whereas our distinctly younger age is from a metapegmatite. These two rock types would behave differently during metamorphism. One way to explain the $\sim 25 \mathrm{Myr}$ age difference between metapegmatite and metabasite ages would be that the metabasite age reflects an earlier high-T metamorphic stage than crystallization of partial melts reflected by our $60.5 \pm 0.7 \mathrm{Ma}$ age. Partial melting and pegmatite intrusions in the metapelite at 60 Ma may have resulted from decompression as is commonly reported from extensional provinces (Harris \& Massey, 1994; Kruckenberg et al., 2008; Ring, Glodny, et al., 2018). This interpretation would imply a rather protracted period of about $25 \mathrm{Myr}$ for high- $\mathrm{T}$ conditions before the rocks were exhumed (inset in Figure 10a).

Apatite fission track dating has identified a Late Cretaceous thermal event at about 80-72 Ma in the Paparoa metamorphic core complex in the Australian Plate (Schulte et al., 2014) that was associated with NE-SW horizontal extension (in present coordinates). Similar Late Cretaceous apatite fission track ages occur in several other places in the South Island (Batt et al., 2004; Kamp, 1997; Lang et al., 2018). Ring, Mortimer, et al. (2018) reported zircon fission track ages of 79 to $46 \mathrm{Ma}$ from the footwall of a normal fault in the Otago Schist. These ages show a systematic and robust age trend indicating NE-SW extension, which probably reactivated a mid-Cretaceous normal fault. Bishop (1992) compiled nearly 400 orientations of Late Cretaceous lamprophyre dikes, revealing a prominent maximum strike at $120^{\circ}$, compatible with NE-SW horizontal extension (see Mortimer, 2018). The interpretation of these, admittedly sparse, upper-crustal thermotectonic data is that Zealandia was affected by a protracted NE-SW-directed extensional event in the Late Cretaceous. 
The Cretaceous low-T ages from Stewart Island have been interpreted to reflect footwall cooling of a normal fault system resulting from NE-SW extension (Kula et al., 2009; Ring et al., 2015). The high-temperature thermochronologic ages would then reflect the deep-crustal response to extension recorded by the low- $\mathrm{T}$ ages in the upper crust.

The opening of the Tasman Sea to the northwest of New Zealand was a protracted event starting before 110 Ma (Schulte et al., 2014) and culminated in mid-ocean ridge formation at $~ 83$ Ma (Gaina et al., 1998). The direction of extension was NE-SW (Schulte et al., 2014; Tulloch \& Kimbrough, 1989). The separation of New Zealand from Antarctica started later by 100 Ma (Uruski \& Ilg, 2006) and the Pacific-Antarctica spreading ridge formed by $\sim 76$ Ma (Gaina et al., 1998), and the extension direction was NE-SW (Kula et al., 2009; Ring et al., 2015). We suggest that the various extension directions reported above are related to these two extension events to the northwest and southeast of the South Island. The large age range reflected by the ages for metamorphism, magmatism, and cooling might be related to these protracted rifting events and suggests that large parts of the lower crust in the South Island were not caught up by extensional structures and remained at depths.

\section{Conclusions}

We dated, for the first time, the end of amphibolite-facies deformation in Alpine Schist mylonite exposed directly above the Alpine Fault. Our Rb-Sr ages cluster between 14 and $10 \mathrm{Ma}$ with a weighted mean age of $10.74 \pm 0.57 \mathrm{Ma}$. The ages indicate that crustal thickening and the formation of a thick crustal root were underway in the middle to late Miocene. P-T data show that the crust was $>35-40$ $\mathrm{km}$ thick at that time. The geothermal gradient in the middle Miocene was not greater than about $10-15{ }^{\circ} \mathrm{C} / \mathrm{km}$ in the ductile crust. A subsequent geochronologically recorded imprint in our Alpine Schist mylonite samples occurred at 2-1 Ma and is interpreted to date cooling from $500 / 450{ }^{\circ} \mathrm{C}$ through $350{ }^{\circ} \mathrm{C}$ at time-averaged cooling rates exceeding $100{ }^{\circ} \mathrm{C} / \mathrm{Myr}$. Temperature-time relations indicate a distinct two-stage history of the currently exposed Alpine Schist with initial slow cooling and moderate exhumation rates of $2-4 \mathrm{~km} / \mathrm{Myr}$ followed by noticeably more rapid cooling since $\sim 2 \mathrm{Ma}$ and also more rapid exhumation at rates of ca. 5-6 km/Myr. We interpret the two-phase cooling history by movement of the mylonite through a strongly nonlinear thermal structure.

\section{Acknowledgments}

AcknowledgementsU. R. and K. A. L. received funding from the Swedish Research Council (Vetenskapsrådet, Project 2016-03461) and U. R. additional funding by the Swedish Wenner-Gren Stiftelserna (Contract SSh2018-0003). We appreciate the help of Cees Passchier and Virginia Toy with interpreting the outcrop deformation fabrics and microstructures and thank Chris Hall for ${ }^{40} \mathrm{Ar} /{ }^{39} \mathrm{Ar}$ analyses and Reuben Hansman for discussions. Brad Hacker, Nick Mortimer, and an anonymous reviewer provided critical and helpful reviews. All data of this manuscript are appropriately cited and referred to in the reference list and available in the supporting information files. They are also available online (https://su.figshare.com/account/ home\#/projects/67418; doi: 10.17045/ sthlmuni.9577454). The sample material is stored at GFZ Potsdam.

\section{References}

Adams, C. J. (1981). Uplift rates and thermal structure in the Alpine fault zone and Alpine schists, Southern Alps, New Zealand, Special Publication, (Vol. 9, pp. 211-222). London: Geological Society. https://doi.org/10.1144/GSL.SP.1981.009.01.19

Ague, J. J., \& Carlson, W. D. (2013). Metamorphism as garnet sees it: The kinetics of nucleation and growth, equilibration, and diffusional relaxation. Elements, 9(6), 439-445. https://doi.org/10.2113/gselements.9.6.439

Allis, R. G., \& Shi, Y. (1995). New insights to temperature and pressure beneath the central Southern Alps, New Zealand. New Zealand Journal of Geology Geophysics, 38(4), 585-592. https://doi.org/10.1080/00288306.1995.9514687

Angiboust, S., Cambeses, A., Hyppolito, T., Glodny, J., Monié, P., Calderón, M., \& Juliani, C. (2018). A 100-my-long window onto mass-flow processes in the Patagonian Mesozoic subduction zone (Diego de Almagro Island, Chile). GSA Bulletin, 130(9-10), 1439-1456. https:// doi.org/10.1130/B31891.1

Angiboust, S., \& Harlov, D. (2017). Ilmenite breakdown and rutile-titanite stability in metagranitoids: Natural observations and experimental results. American Mineralogist, 102(8), 1696-1708. https://doi.org/10.2138/am-2017-6064

Batt, G. E., Baldwin, S. L., Cottam, M., Fitzgerald, P. G., Brandon, M. T., \& Spell, T. L. (2004). Cenozoic plate boundary evolution in the South Island of New Zealand: New thermochronological constraints. Tectonics, 23, TC4001. https://doi.org/10.1029/2003TC001527

Batt, G. E., Braun, J., Kohn, B. P., \& McDougall, I. (2000). Thermochronological analysis of thedynamics of the Southern Alps, New Zealand. Geological Society of America Bulletin, 112(2), 250-266. https://doi.org/10.1130/0016-7606

Batt, G. E., Kohn, B. P., Braun, J., McDougall, I., \& Ireland, T. R. (1999). New insight into the dynamic development of the Southern Alps, New Zealand, from detailed thermochronological investigation of the Mataketake Range pegmatites, Special Publications, (Vol. 154, pp. 261-282 ). London: Geological Society. https://doi.org/10.1144/GSL.SP.1999.154.01.12

Beavan, J., Denys, P., Denham, M., Herring, T., \& Molnar, P. (2010). Distribution of present-day vertical deformation across the Southern Alps, New Zealand, from 10 years of GPS data. Geophysical Research Letters, 37, L16305. https://doi.org/10.1029/2010GL044165

Beavan, J., Tregoning, P., Bevis, M., Kato, T., \& Meertens, C. (2002). The motion and rigidity of the Pacific Plate and implications for plate boundary deformation. Journal of Geophysical Research, 107(B10), 2261. https://doi.org/10.1029/2001JB000282

Beavan, J., Wallace, L. M., Palmer, N., Denys, P., Ellis, S., Fournier, N., et al. (2016). New Zealand GPS velocity field: 1995-2013. New Zealand Journal of Geology and Geophysics, 59, 5-14. https://doi.org/10.1080/00288306.2015.1112817

Bishop, D. J. (1992). Extensional tectonism and magmatism during the middle Cretaceous to Paleocene, North Westland, New Zealand. New Zealand Journal of Geology and Geophysics, 35(1), 81-91. https://doi.org/10.1080/00288306.1992.9514502

Briggs, S., Cottle, J., \& Smit, M. (2018). Record of plate boundary metamorphism during Gondwana breakup from Lu-Hf garnet geochronology of the Alpine Schist. New Zealand Journal Metamorphic Geology, 36(7), 821-841. https://doi.org/10.1111/jmg.12313

Cande, S. C., \& Stock, J. M. (2004). Pacific-Antarctic-Australia motion and the formation of the Macquarie Plate. Geophysical Journal International, 157, 399-414. https://doi.org/10.1111/j.1365-246X.2004.02224.X 
Carlson, W. D. (2011). Porphyroblast crystallization: Linking processes, kinetics, and microstructures. International Geology Review, 53(3-4), 406-445. https://doi.org/10.1080/00206814.2010.496184

Chamberlain, C. P., Zeitler, P. K., \& Cooper, A. F. (1995). Geochronologic constraints of the uplift and metamorphism along the Alpine Fault, South Island, New Zealand. New Zealand Journal of Geology and Geophysics, 38(4), 515-523. https://doi.org/10.1080/ 00288306.1995 .9514678

Cooper, A. F. (1974). Multiphase deformation and its relation to metamorphic crystallization at Haast River South Westland, New Zealand. New Zealand Journal of Geology and Geophysics, 14, 855-900. https://doi.org/10.1080/00288306.1974.10418230

Cooper, A. F. (1980). Retrograde alteration of chromian kyanite in metachert and amphibolite whiteschist from the Southern Alps, New Zealand. New Zealand Journal of Geology and Geophysics, 17, 855-880.

Cooper, A. F., Barreiro, B. A., Kimbrough, D. L., \& Mattinson, J. M. (1987). Lamprophyre dike intrusion and the age of the Alpine fault, New Zealand. Geology, 15(10), 941-944. https://doi.org/10.1130/0091-7613(1987)15<941:LDIATA>2.0.CO;2

Cooper, A. F., \& Palin, J. M. (2018). Two-sided accretion and polyphase metamorphism in the Haast Schist belt, New Zealand: Constraints from detrital zircon geochronology. GSA Bulletin, 130(9-10), 1501-1518. https://doi.org/10.1130/B31826.1

Cox, S. C., \& Barrell, D. J. A. (2007). Geology of the Aoraki area, scale 1:250,000. Lower Hutt: GNS Science. Institute of Geological \& Nuclear Sciences.

Cox, S. C., \& Findlay, R. H. (1995). The Main Divide Fault Zone and its role in formation of the Southern Alps, New Zealand. New Zealand Journal Geology Geophysics, 38(4), 489-499. https://doi.org/10.1080/00288306.1995.9514675

Cox, S. C., Stirling, M. W., Herman, F., Gerstenberger, M., \& Ristau, J. (2012). Potentially active faults in the rapidly eroding landscape adjacent to the Alpine Fault, central Southern Alps, New Zealand. Tectonics, 31, TC2011. https://doi.org/10.1029/2001JB000884

Cox, S. C., \& Sutherland, R. (2007). Regional geological framework of South Island, New Zealand, and its significance for understanding the active plate boundary. p. 19-46. In D. Okaya, T. Stern, \& F. Davey (Eds.), A continental plate boundary: Tectonics at South Island, New Zealand, Geophysical Monograph Series, (Vol. 175, pp. 271-288). Washington, DC: American Geophysical Union.

Craw, D. (1997). Fluid inclusion evidence for geothermal structure beneath the Southern Alps, New Zealand. New Zealand Journal Geology Geophysics, 40(1), 43-52. https://doi.org/10.1080/00288306.1997.9514739

Craw, D., Rattenbury, M. S., \& Johnstone, R. D. (1994). Structures within greenschist facies Alpine Schist, central Southern Alps, New Zealand. New Zealand Journal of Geology and Geophysics, 37(1), 101-111. https://doi.org/10.1080/00288306.1994.9514603

Cutten, H. N. C., Korsch, R. J., \& Roser, B. P. (2006). Using geochemical fingerprinting to determine transpressive fault movement history: Application to the New Zealand Alpine Fault. Tectonics, 25, TC4014. https://doi.org/10.1029/2005TC001842

Davey, F. J., Eberhart-Philipps, D., Kohler, M., Bannister, S., Caldwell, G., Henrys, S., et al. (1998). Geophysial structure of the Southern Alps orogen, South Island, New Zealand. In D. Okaya, T. Stern, \& F. Davey (Eds.), A continental plate boundary: Tectonics at South Island, New Zealand, Geophysical Monograph Series (Vol. 175, pp. 47-76). Washington, DC: American Geophysical Union.

DeMets, C., Gordon, R. G., \& Argus, D. F. (2010). Geologically current plate motions. Geophysical Journal International, 181(1), 1-80. https://doi.org/10.1111/j.1365-246X.2009.04491.x

Dutch, R., \& Hand, M. (2010). Retention of Sm-Nd isotopic ages in garnets subjected to high-grade thermal reworking: Implications for diffusion rates of major and rare earth elements and the Sm-Nd closure temperature in garnet. Contributions to Mineralogy and Petrology, 159(1), 93-112. https://doi.org/10.1007/s00410-009-0418-1

Eberlei, T., Habler, G., Wegner, W., Schuster, R., Körner, W., Thöni, M., \& Abart, R. (2015). Rb/Sr isotopic and compositional retentivity of muscovite during deformation. Lithos, 227, 161-178. https://doi.org/10.1016/j.lithos.2015.04.007

Egli, D., Müller, W., \& Mancktelow, N. (2016). Laser-cut Rb-Sr microsampling dating of deformational events in the Mont Blanc-Aiguilles Rouges region (European Alps). Terra Nova, 28(1), 35-42. https://doi.org/10.1111/ter.12184

Engvik, A. K., Golla-Schindler, U., Berndt, J., Austrheim, H., \& Putnis, A. (2009). Intragranular replacement of chlorapatite by hydroxyfluor-apatite during metasomatism. Lithos, 112(3-4), 236-246. https://doi.org/10.1016/j.lithos.2009.02.005

Findlay, R. H. (1987). Structure and interpretation of the Alpine schists in Copeland and Cook River Valleys, South Island, New Zealand. New Zealand Journal of Geology and Geophysics, 30(2), 117-138. https://doi.org/10.1080/00288306.1987.10422178

Furlong, K. P., \& Kamp, P. J. J. (2009). The lithospheric geodynamics of plate boundary transpression in New Zealand: Initiating and emplacing subduction along the Hikurangi margin, and the tectonic evolution of the Alpine Fault system. Tectonophysics, 474, 449-462. https://doi.org/10.1016/j.tecto.2009.04.023

Gaina, C., Müller, D. R., Royer, J. Y., Stock, J., Hardebeck, J., \& Symonds, P. (1998). The tectonic history of the Tasman Sea: A puzzle with 13 pieces. Journal of Geophysical Research, 103(B6), 12,413-12,433. https://doi.org/10.1029/98JB00386

Ghisetti, F., Sibson, R. H., \& Hamling, I. (2016). Deformed Neogene basins, active faulting and topography in Westland: Distributed crustal mobility west of the Alpine Fault transpression zone. Tectonophysics, 693, 340-362. https://doi.org/10.1016/j.tecto.2016.03.024

Glodny, J., Austrheim, H., Molina, J. F., Rusin, A. I., \& Seward, D. (2003). Rb/Sr record of fluid-rock interaction in eclogites: The Marun-Keu complex, Polar Urals, Russia. Geochimica et Cosmochimica Acta, 67(22), 4353-4371. https://doi.org/10.1016/S0016-7037 (03)00370-3

Glodny, J., Grauert, B., Fiala, J., Vejnar, Z., \& Krohe, A. (1998). Metapegmatites in the western Bohemian massif: Ages of crystallisation and metamorphic overprint, as constrained by U-Pb zircon, monazite, garnet, columbite and Rb-Sr muscovite data. Geologische Rundschau, 87(1), 124-134. https://doi.org/10.1007/s005310050194

Glodny, J., Ring, U., \& Kühn, A. (2008). Coeval high-pressure metamorphism, thrusting, strike-slip, and extensional shearing in the Tauern Window, Eastern Alps. Tectonics, 27, TC4004. https://doi.org/10.1029/2007TC002193

Glodny, J., Ring, U., Kühn, A., Gleissner, P., \& Franz, G. (2005). Crystallization and very rapid exhumation of the youngest Alpine eclogites (Tauern Window, Eastern Alps) from Rb/Sr mineral assemblage analysis. Contributions Mineralogy Petrology, 149, 699-712.https://doi. org/10.1007/s00410-005-0676-5

Grapes, R., Vry, J.K. 1999. Garnet compositions track early, later and latest phases of Alpine Schist metamorphism, Central Southern Alps, New Zealand: Geological Society, New Zealand, Miscellaneous Publication, Vo. 107A, p. 51

Grapes, R., \& Watanabe, T. (1992). Metamorphism and uplift of Alpine schist in the Franz Josef-Fox Glacier area of the Southern Alps, New Zealand. Journal of Metamorphic Geology, 10(2), 171-180. https://doi.org/10.1111/j.1525-1314.1992.tb00077.x

Grapes, R. H. (1995). Uplift and exhumation of Alpine schist, Southern Alps, New Zealand: Thermobarometric constraints. New Zealand Journal Geology Geophysics, 38(4), 525-533. https://doi.org/10.1080/00288306.1995.9514679

Grapes, R. H., \& Watanabe, T. (1994). Mineral composition variation in Alpine Schist, Southern Alps, New Zealand: Implications for recrystallization and exhumation. Island Arc, 3(3), 163-181. https://doi.org/10.1111/j.1440-1738.1994.tb00105.x

Harris, N., \& Massey, J. (1994). Decompression and anatexis of Himalayan metapelites. Tectonics, 13(6), 1537-1546. https://doi.org/ 10.1029/94TC01611 
Harrison, T. M., \& McDougall, I. D. (1985). Diffusion of ${ }^{40} \mathrm{Ar}$ in biotite: Temperature, pressure and compositional effects. Geochimica et Cosmochimica Acta, 49, 2461-2468. https://doi.org/10.1016/0016-7037(85)90246-7

Heri, A. R., Robyr, M., \& Villa, I. M. (2014). Petrology and geochronology of 'muscovite age standard' B4M, (Vol. 378, pp. 69-78). London: Geological Society, Special Publications. https://doi.org/10.1144/SP378.2

Herman, F. S., Braun, J., \& Dunlap, W. J. (2007). Tectonomorphic scenarios in the Southern Alps of New Zealand. Journal of Geophysical Research, 112, B04201. https://doi.org/10.1029/2004JB003472

Holm, D. K., Norris, R. J., \& Craw, D. (1989). Brittle and ductile deformation in a zone of rapid uplift: Central Southern Alps, New Zealand. Tectonics, 8(2), 153-168. https://doi.org/10.1029/TC008i002p00153

Horton, T. W., Defliese, W. F., Tripati, A. K., \& Oze, C. (2016). Evaporation induced ${ }^{18} \mathrm{O}$ and ${ }^{13} \mathrm{C}$ enrichment in lake systems: A global perspective on hydrologic balance effects. Quaternary Science Reviews, 131, 365-379. https://doi.org/10.1016/j.quascirev.2015.06.030

Hovius, N., Stark, C. P., \& Allen, P. A. (1997). Sediment flux from a mountain belt derived from landslide mapping. Geology, 25(3), 231-234. https://doi.org/10.1130/0091-7613(1997)0252.3.CO;2

Hyppolito, T., Cambeses, A., Angiboust, S., Raimondo, T., García-Casco, A., \& Juliani, C. (2019). Rehydration of eclogites and garnetreplacement processes during exhumation in the amphibolite facies, Special Publications, (Vol. 478, pp. 217-239). London: Geological Society. https://doi.org/10.1144/SP478.3

Kamp, P. J. J. (1986). The mid-Cenozoic Challenger Rift System of western New Zealand and its implications for the age of Alpine fault inception. Geological Society of America Bulletin, 97, 255-281. https://doi.org/10.1130/0016-7606(1986)97<255:TMCRSO>2.0. $\mathrm{CO} ; 2$

Kamp, P. J. J. (1997). Paleogeothermal gradient and deformation style, Pacific front of the Southern Alps Orogen: Constraints from fission track thermochronology. Tectonophysics, 271(1-2), 37-58. https://doi.org/10.1016/S0040-1951(96)00246-6

Kamp, P. J. J., Green, P. F., \& White, S. H. (1989). Fission track analysis reveals character of collisional tectonics in New Zealand. Tectonics, 8(2), 169-195. https://doi.org/10.1029/TC008i002p00169

Kidder, S. B., Toy, V. G., Prior, D. J., Little, T. A., Khan, A., \& MacRae, C. (2018). Constraints on Alpine Fault (New Zealand) mylonitization temperatures and geothermal gradient from Ti-in-quartz thermobarometry. Solid Earth Discussions, 9(5), 1123-1139. https://doi.org/ $10.5194 / \mathrm{se}-2018-12$

King, P. R., Naish, T. R., Browne, G. H., Field, B. D., \& Edbrooke, S. W. (1999). Cretaceous to Recent sedimentary patterns in New Zealand, Institute of Geological \& Nuclear Sciences Folio Series 1, (). Lower Hutt: Institute of Geological \& Nuclear Sciences.

Kleffman, S., Davey, F., Melhuish, A., Okaya, D., Stern, T., \& SIGHT team (1998). Crustal structure in the central South Island, New Zealand, from the Lake Pukaki seismic experiment. New Zealand Journal Geology Geophysics, 41(1), 39-49. https://doi.org/10.1080/ 00288306.1998 .9514789

Koons, P. O. (1987). Some thermal and mechanical consequences of rapid uplift: an example from the Southern Alps, New Zealand. Earth and Planetary Science Letters, 86(2-4), 307-319. https://doi.org/10.1016/0012-821X(87)90228-7

Koons, P. O. (1990). Two-sided orogen: Collision and erosion from the sand-box to the Southern Alps of New Zealand. Geology, 18, 679-682. https://doi.org/10.1130/0091-7613(1990)0182.3.CO;2

Kruckenberg, S. C., Whitney, D. L., Teyssier, C., Fanning, C. M., \& Dunlap, W. J. (2008). Paleocene-Eocene migmatite crystallization, extension, and exhumation in the hinterland of the northern Cordillera: Okanogan dome, Washington, USA. Geological Society of America Bulletin, 120(7-8), 912-929. https://doi.org/10.1130/B26153.1

Kula, J., Tulloch, A. J., Spell, T. L., Wells, M. L., \& Zanetti, K. A. (2009). Thermal evolution of the Sisters shear zone, southern New Zealand; formation of the Great South Basin and onset of Pacific-Antarctic spreading. Tectonics, 28, TC5015. https://doi.org/10.1029/ 2008TC002368

Kumerics, C., Ring, U., Brichau, S., Glodny, J., \& Monie, P. (2005). The extensional Ikaria shear zone and associated brittle detachments faults, Aegean Sea, Greece. Journal of the Geological Society of London, 162(4), 701-721. https://doi.org/10.1144/0016-764904-041

Kusebauch, C., John, T., Whitehouse, M. J., Klemme, S., \& Putnis, A. (2015). Distribution of halogens between fluid and apatite during fluid-mediated replacement processes. Geochimica et Cosmochimica Acta, 170, 225-246. https://doi.org/10.1016/j.gca.2015.08.023

Küster, D. (1995). Rb-Sr isotope systematics of muscovite from Pan-African granitic pegmatites of Western and Northeastern Africa. Mineralogy and Petrology, 55(1-3), 71-83. https://doi.org/10.1007/BF01162580

Lamb, S., Smith, E., Stern, T., \& Warren-Smith, E. (2015). Continent scale strike-slip on a low-angle fault beneath New Zealand's Southern Alps: Implications for crustal thickening in oblique collision zones. Geochemistry, Geophysics, Geosystems, 16, 3076-3096. https://doi. org/10.1002/2015GC005990

Lang, K.A., Glotzbach, C.; Ring, U.; Kamp, P.J.J.; Ehlers, T.A. 2018. Emergence of an exhumation feedback in the Southern Alps of New Zealand: New observations from detrital thermochronology of the Waiho-1 Borehole. American Geophysical Union, Fall Meeting 2018, abstract \#T52A-05. 2018AGUFM.T52A..05L.

Lee, J. K., Williams, I. S., \& Ellis, D. J. (1997). Pb, U and Th diffusion in natural zircon. Nature, 390(6656), 159-162. https://doi.org/10.1038/ 36554

Leitner, B., Eberhart-Phillips, D., Anderson, H., \& Nabelek, J. L. (2001). A focused look at the Alpine fault, New Zealand: Seismicity, focal mechanisms, and stress observations. Journal of Geophysical Research, 106(B2), 2193-2220. https://doi.org/10.1029/2000JB900303

Little, T. A. (2004). Transpressive ductile flow and oblique ramping of lower crust in a two-sided orogen: Insight from quartz grain-shape fabrics near the Alpine Fault, New Zealand. Tectonics, 23, TC2013. https://doi.org/10.1029/2002TC0011456

Little, T. A., Cox, S., Vry, J. K., \& Batt, G. (2005). Variations in exhumation level and uplift along the oblique-slip Alpine fault, central Southern Alps, New Zealand. Geological Society of America Bulletin, 117, 707-723. https://doi.org/10.1130/B25500.1

Little, T. A., \& Holcombe, R. J. (2002). Kinematics of oblique collision and ramping inferred from microstructures and strain in middle crustal rocks, central Southern Alps, New Zealand. Journal of Structural Geology, 24(1), 219-239. https://doi.org/10.1016/S0191-8141(01) 00060-8

Little, T. A., Holcombe, R. J., \& Ilg, B. R. (2002). Ductile fabrics in the zone of active oblique convergence near the Alpine Fault, New Zealand: Identifying the neotectonic overprint. Journal of Structural Geology, 24, 193-217. https://doi.org/10.1016/S0191-8141(01) 00059-1

Little, T. A., Prior, D. J., \& Toy, V. G. (2016). Are quartz LPOs predictably oriented with respect to the shear zone boundary? - A test from the Alpine Fault mylonites, New Zealand. Geochemistry, Geophysics, Geosystems (G-Cubed, 17, 981-999, 2015GC006145R. https://doi. org/10.1002/2015GC006145

Little, T. A., Prior, D. J., Toy, V. G., \& Lindroos, Z. R. (2015). The link between strength of lattice preferred orientation, second phase content and grain boundary migration: A case study from near the Alpine Fault, New Zealand. Journal of Structural Geology, 81, 59-77. https://doi.org/10.1016/j.jsg.2015.09.004 
Little, T. A., Wightman, H. R. J. R., \& Hill, M. (2007). Transpression models and ductile deformation of the lower crust of the Pacific Plate in the central Southern Alps, a perspective from structural geology. In D. Okaya, T. Stern, \& F. Davey (Eds.), A Continental Plate Boundary: Tectonics at South Island, New Zealand, Geophys. Monogr. Ser, (Vol. 175, pp. 271-288). Washington, DC: American Geophysical Union.

Lu, H., \& Fulthorpe, C. S. (2004). Controls on sequence stratigraphy of a middle Miocene-Holocene, current-swept, passive margin: Offshore Canterbury Basin, New Zealand. Geological Society of America Bulletin, 116(11-12), 1345-1366. https://doi.org/10.1130/ B2525401.1

Mancktelow, N., \& Pennacchioni, G. (2004). The influence of grain boundary fluids on the microstructure of quartz-feldspar mylonites. Journal of Structural Geology, 26, 47-69. https://doi.org/10.1016/S0191-8141(03)00081-6

Mortimer, N. (2000). Metamorphic discontinuities in orogenic belts: Example of the garnet-biotite-albite zone in the Otago Schist, New Zealand. International Journal of Earth Sciences, 89(2), 295-306. https://doi.org/10.1007/s005310000086

Mortimer, N. (2018). Evidence for a pre-Eocene proto-Alpine Fault through Zealandia. New Zealand Journal of Geology and Geophysics, 61(3), 251-259. https://doi.org/10.1080/00288306.2018.1434211

Mortimer, N., \& Cooper, A. F. (2004). U-Pb and Sm-Nd ages from the Alpine Schist, New Zealand. New Zealand Journal of Geology and Geophysics, 47(1), 21-28. https://doi.org/10.1080/00288306.2004.9515034

Müller, W., Mancktelow, N. S., \& Meier, M. (2000). Rb-Sr microchrons of synkinematic mica in mylonites: An example from the DAV fault of the Eastern Alps. Earth and Planetary Science Letters, 180(3-4), 385-397. https://doi.org/10.1016/S0012-821X(00)00167-9

Norris, R. J., \& Cooper, A. F. (1995). Origin of small-scale segmentation and transpressional thrusting along the Alpine fault, New Zealand. Geological Society of America Bulletin, 107(2), 231-240. https://doi.org/10.1130/0016-7606(1995)1072.3.CO;2

Norris, R. J., \& Cooper, A. F. (2001). Late Quaternary slip rates and slip partitioning on the Alpine fault, New Zealand. Journal of Structural Geology, 32(3), 620-640. https://doi.org/10.1002/tect.20041

Norris, R. J., \& Cooper, A. F. (2003). Very high strains recorded in mylonites along the Alpine fault, New Zealand: Implication for the deep structure of plate boundary faults. Journal of Structural Geology, 25(12), 2141-2157. https://doi.org/10.1016/S0191-8141(03) 00045-2

Norris, R. J., \& Cooper, A. F. (2007). The Alpine Fault, New Zealand: Surface geology and field relationships. In D. Okaya, T. Stern, \& F. Davey (Eds.), A continental plate boundary: Tectonics at South Island, New Zealand, Geophysical Monograph Series, (Vol. 175, pp. 157-175). Washington, DC: American Geophysical Union.

Norris, R. J., Koons, P. O., \& Cooper, A. F. (1990). The obliquely-convergent plate boundary in the South Island of New Zealand: Implications for ancient collision zones. Journal of Structural Geology, 12(5-6), 715-725. https://doi.org/10.1016/0191-8141(90)90084-C

Norris, R. J., \& Toy, V. G. (2014). Continental transforms: A view from the Alpine Fault. Journal of Structural Geology, 64, 3-31. https://doi. org/10.1016/j.jsg.2014.03.003

Okaya, D. A., Stern, T. A., Davey, F. J., Henrys, S. A., \& Cox, S. C. (2007). Continent-continent collision at the Pacific/Indo-Australian plate boundary: Background, motivation, and principal results. p. 1-18. In D. Okaya, T. Stern, \& F. Davey (Eds.), A continental plate boundary: Tectonics at South Island, New Zealand, Geophysical Monograph Series, (Vol. 175, pp. 271-288). Washington, DC: American Geophysical Union.

Palin, R. M., White, R. W., Green, E. C., Diener, J. F., Powell, R., \& Holland, T. J. (2016). High-grade metamorphism and partial melting of basic and intermediate rocks. Journal of Metamorphic Geology, 34(9), 871-892. https://doi.org/10.1111/jmg.12212

Passchier, C. W., \& Trouw, R. A. J. (2005). Microtectonics, (p. 366). Berlin: Springer.

Platt, J. P., \& Behr, W. M. (2011). Grainsize evolution in ductile shear zones: Implications for strain localization and the strength of the lithosphere. Journal of Structural Geology, 33(4), 537-550. https://doi.org/10.1016/j.jsg.2011.01.018

Putnis, A. (2009). Mineral replacement reactions. Reviews in Mineralogy and Geochemistry, 70(1), 87-124. https://doi.org/10.2138/ rmg.2009.70.3

Rattenbury, M. S. (1987). Timing of mylonitisation west of the Alpine Fault, central Westland, New Zealand. New Zealand Journal of Geology and Geophysics, 30(3), 287-297. https://doi.org/10.1080/00288306.1987.10552623

Reddy, S. M., Wheeler, J., Butler, R. W. H., Cliff, R. A., Freeman, S., Inger, S., \& Kelley, S. P. (2003). Kinematic reworking and exhumation within the convergent Alpine Orogen. Tectonophysics, 365(1-4), 77-102. https://doi.org/10.1016/S0040-1951(03)00017-9

Reiners, P. W., Spell, T. L., Nicolescu, S., \& Zanetti, K. A. (2004). Zircon (U-Th)/He thermochronometry: He diffusion and comparison with ${ }^{40} \mathrm{Ar} /{ }^{39} \mathrm{Ar}$ dating. Geochimica et Cosmochimica Acta, 68(8), 1857-1887. https://doi.org/10.1016/j.gca.2003.10.021

Ring, U., \& Bernet, M. (2010). Fission-track analysis unravels the denudation history of the Bonar Range in the footwall of the Alpine Fault, South Island, New Zealand. Geological Magazine, 147(6), 801-813. https://doi.org/10.1017/S0016756810000208

Ring, U., Glodny, J., Peillod, A., \& Skelton, A. (2018). The timing of high-temperature conditions and ductile shearing in the footwall of the Naxos extensional fault system, Aegean Sea, Greece. Tectonophysics, 745, 366-381. https://doi.org/10.1016/j.tecto.2018.09.001

Ring, U., Mortimer, N., Butz, C., \& Bernet, M. (2018). Extensional deformation along the Footwall Fault below the Hyde-Macraes Shear Zone, Otago Schist, New Zealand. New Zealand Journal of Geology and Geophysics, 61, 219-236. https://doi.org/10.1080/ 00288306.2018.1467471

Ring, U., Tulloch, A., \& Bernet, M. (2015). Kinematic, finite strain and vorticity analysis of the Sisters Shear Zone, Stewart Island, New Zealand. Journal of Structural Geology, 73, 1114-1129. https://doi.org/10.1016/j.jsg.2015.02.004

Ring, U., Uysal, I. T., Glodny, J., Cox, S. C., Little, T., Thomson, S. N., et al. (2017). Fault-gouge dating in the Southern Alps, New Zealand. Tectonophysics, 717, 321-338. https://doi.org/10.1016/j.tecto.2017.08.007

Scherer, E. E., Cameron, K. L., \& Blichert-Toft, J. (2000). Lu-Hf garnet geochronology: Closure temperature relative to the Sm-Nd system and the effects of trace mineral inclusions. Geochimica et Cosmochimica Acta, 64(19), 3413-3432. https://doi.org/10.1016/S0016-7037 (00)00440-3

Schulte, D. O., Ring, U., Thomson, S. N., Glodny, J., \& Carrad, H. (2014). Two-stage development of the Paparoa Metamorphic Core Complex, West Coast, South Island, New Zealand: Hot continental extension precedes sea-floor spreading by 25 my. Lithosphere, 6(3), 177-194. https://doi.org/10.1130/L348.1

Scott, J. M., Auer, A., Muhling, J. R., Czertowicz, T. A., Cooper, A. F., Billia, M. A., \& Kennedy, A. K. (2015). New P-T and U-Pb constraints on Alpine Schist metamorphism in south Westland, New Zealand. New Zealand Journal of Geology and Geophysics, 58(4), 385-397. https://doi.org/10.1080/00288306.2015.1093005

Sibson, R. H., White, S. H., \& Atkinson, B. K. (1981). Structure and distribution of fault rocks in the Alpine Fault Zone, New Zealand, Special Publication, (Vol. 9, pp. 197-210). London: Geological Society of London. https://doi.org/10.1144/GSL.SP.1981.009.01.18

Simpson, G. D., Cooper, A. F., Norris, R. J., \& Turnbull, I. M. (1994). Late Quaternary evolution of the Alpine Fault Zone at Paringa, South Westland, New Zealand. New Zealand Journal of Geology and Geophysics, 37(1), 49-58. https://doi.org/10.1080/ 00288306.1994 .9514600 
Sircombe, K. N., \& Kamp, P. J. J. (1998). The South Westland Basin: Seismic stratigraphy, basin geometry and evolution of a foreland basin within the Southern Alps collision zone, New Zealand. Tectonophysics, 300(1-4), 359-387. https://doi.org/10.1016/S0040-1951 (98)00254-6

Skelton, A. D. L. (1997). The effect of metamorphic fluid flow on the nucleation and growth of garnets from Troms, North Norway. Journal of Metamorphic Geology, 15(1), 85-92. https://doi.org/10.1111/j.1525-1314.1997.t01-1-00051.x

Smit, M. A., Scherer, E. E., \& Mezger, K. (2013). Lu-Hf and Sm-Nd garnet geochronology: Chronometric closure and implications for dating petrological processes. Earth and Planetary Science Letters, 381, 222-233. https://doi.org/10.1016/j.epsl.2013.08.046

Smye, A. J., Warren, C. J., \& Bickle, M. J. (2013). The signature of devolatisation: Extraneous ${ }^{40}$ Ar systematics in high-pressure metamorphic rocks. Geochimica et Cosmochimica Acta, 113, 94-112. https://doi.org/10.1016/j.gca.2013.03.018

Stern, T., Okaya, D., Kleffmann, S., Scherwath, M., Henrys, S., \& Davey, F. (2007). Geophysical exploration and dynamics of the Alpine fault zone. A continental plate boundary. In Tectonics at South Island, New Zealand, Geophysical Monograph Series, (Vol. 175, pp. 207-233). Washington, DC: American Geophysical Union.

Stüwe, K., \& Hintermüller, M. (2000). Topography and isotherms revisited: The influence of laterally migrating drainage divides. Earth and Planetary Science Letters, 184(1), 287-303. https://doi.org/10.1016/S0012-821X(00)00315-0

Sutherland, R. (1995). The Australia-Pacific boundary and Cenozoic plate motions in the SW Pacific: Some constraints from Geosat data. Tectonics, 14(4), 819-831. https://doi.org/10.1029/95TC00930

Sutherland, R. (1996). Transpressional development of the Australia-Pacific boundary through southern South Island, New Zealand: Constraints from Miocene-Pliocene sediments, Waiho-1 borehole, South Westland. New Zealand Journal Geology Geophysics, 39(2), 251-264. https://doi.org/10.1080/00288306.1996.9514709

Sutherland, R., Townend, J., Upton, P., Coussens, J., Allen, M., Baratin, L.-M., et al. (2017). Extreme hydrothermal conditions at an active plate-bounding fault. Nature, 546(7656), 137-140. https://doi.org/10.1038/nature22355

Tippett, J. M., \& Kamp, P. J. J. (1993). Fission track analysis of the late Cenozoic vertical kinematics of continental Pacific crust, South Island, New Zealand. Journal of Geophysical Research, 98(B9), 16,119-16,148. https://doi.org/10.1029/92JB02115

Toy, V. G., Craw, D., Cooper, A. F., \& Norris, R. J. (2010). Thermal regime in the central Alpine Fault zone, New Zealand: Constraints from microstructures, biotite chemistry and fluid inclusion data. Tectonophysics, 485(1-4), 178-192. https://doi.org/10.1016/j. tecto.2009.12.013

Toy, V. G., Prior, D. J., \& Norris, R. J. (2008). Quartz fabrics in the Alpine Fault mylonites: Influence of pre-existing preferred orientations on fabric development during progressive uplift. Journal of Structural Geology, 30(5), 602-621. https://doi.org/10.1016/j.jsg.2008.01.001

Tulloch, A. J., \& Kimbrough, D. L. (1989). The Paparoa Metamorphic Core Complex, Westland-Nelson, New Zealand: Cretaceous extension associated with fragmentation of the Pacific margin of Gondwana. Tectonics, 8(6), 1217-1134. https://doi.org/10.1029/ TC008i006p01217

Uruski, C., Ilg, B., 2006. Preliminary interpretation and structural modelling of DUN06 seismic reflection data from Great South Basin, Offshore New Zealand. GNS Science Consultancy, p. 46. Report 2006/233.

Villa, I. M. (2010). Disequilibrium textures versus equilibrium modelling: Geochronology at the crossroads, Special Publications, (Vol. 332, pp. 1-15). London: Geological Society. https://doi.org/10.1144/SP332.1

Villa, I. M. (2016). Diffusion in mineral geochronometers: Present and absent. Chemical Geology, 420, 1-10. https://doi.org/10.1016/j. chemgeo.2015.11.001

Vry, J. K., Baker, J., Maas, R., Little, T. A., Grapes, R., \& Dixon, M. (2004). Zoned (Cretaceous and Cenozoic) garnet and the timing of high grade metamorphism, Southern Alps, New Zealand. Journal of Metamorphic Geology, 22(3), 137-157. https://doi.org/10.1111/j.15251314.2004.00504.x

Walcott, R. I. (1998). Modes of oblique compression: Late Cenozoic tectonics of the South Island of New Zealand. Reviews of Geophysics, 36, 1-26. https://doi.org/10.1029/97RG03084

Wannamaker, P. E., Jiracek, G. R., Stodt, J. A., Caldwell, T. G., Gonzalez, V. M., McKnight, J. D., \& Porter, A. D. (2002). Fluid generation and pathways beneath an active compressional orogen, the New Zealand Southern Alps, inferred from magnetotelluric data. Journal of Geophysical Research, 107(B6), 2117. https://doi.org/10.1029/2001JB000186

Warren, C. J., Hanke, F., \& Kelley, S. P. (2012). When can muscovite ${ }^{40} \mathrm{Ar} /{ }^{39}$ Ar dating constrain the timing of metamorphic exhumation? Chemical Geology, 291, 79-86. https://doi.org/10.1016/j.chemgeo.2011.09.017

Wellman, H. W. (1979). An uplift map for the South Island of New Zealand, and a model for uplift of the Southern Alps. Royal Society of New Zealand Bulletin, 18, 13-20.

White, S. (1996). Composition and zoning of garnet and plagioclase in Haast Schist, northwest Otago, New Zealand: Implications for progressive regional metamorphism. New Zealand Journal of Geology and Geophysics, 39(4), 515-531. https://doi.org/10.1080/ 00288306.1996 .9514730

Willett, S. D. (1999). Orogeny and orography: The effects of erosion on the structure of mountain belts. Journal of Geophysical Research, 104(B12), 28,957-28,981. https://doi.org/10.1029/1999JB900248

Willett, S. D., Beaumont, C., \& Fullsack, P. (1993). Mechanical model for the tectonics of doubly vergent compressional orogens. Geology, 21(4), 371-374. https://doi.org/10.1130/0091-7613(1993)021<0371:MMFTTO>2.3.CO;2

Yardley, B. W. D. (1982). The early metamorphic history of the Haast Schist and related rocks of New Zealand. Contributions to Mineralogy and Petrology, 81(4), 317-327. https://doi.org/10.1007/BF00371686 